\title{
Scavenger Receptors and Their Potential as Therapeutic Targets in the Treatment of Cardiovascular Disease
}

\author{
Sam L. Stephen, ${ }^{1}$ Katie Freestone, ${ }^{1}$ Sarah Dunn, ${ }^{1}$ Michael W. Twigg, ${ }^{1,2}$ \\ Shervanthi Homer-Vanniasinkam, ${ }^{1,2}$ John H. Walker, ${ }^{1}$ Stephen B. Wheatcroft, ${ }^{3}$ \\ and Sreenivasan Ponnambalam ${ }^{1}$ \\ ${ }^{1}$ Endothelial Cell Biology Unit, Institute of Molecular \& Cellular Biology, LIGHT Laboratories, University of Leeds, \\ Clarendon Way, Leeds LS2 9JT, UK \\ ${ }^{2}$ Leeds Vascular Institute, Leeds General Infirmary, Great George Street, Leeds LS1 3EX, UK \\ ${ }^{3}$ Academic Unit of Molecular and Vascular Medicine, Faculty of Medicine and Health, LIGHT Laboratories, University of Leeds, \\ Clarendon Way, Leeds LS2 9JT, UK
}

Correspondence should be addressed to Sreenivasan Ponnambalam, s.ponnambalam@leeds.ac.uk

Received 6 May 2010; Accepted 7 July 2010

Academic Editor: Stephen B. Harrap

Copyright ( 2010 Sam L. Stephen et al. This is an open access article distributed under the Creative Commons Attribution License, which permits unrestricted use, distribution, and reproduction in any medium, provided the original work is properly cited.

\begin{abstract}
Scavenger receptors act as membrane-bound and soluble proteins that bind to macromolecular complexes and pathogens. This diverse supergroup of proteins mediates binding to modified lipoprotein particles which regulate the initiation and progression of atherosclerotic plaques. In vascular tissues, scavenger receptors are implicated in regulating intracellular signaling, lipid accumulation, foam cell development, and cellular apoptosis or necrosis linked to the pathophysiology of atherosclerosis. One approach is using gene therapy to modulate scavenger receptor function in atherosclerosis. Ectopic expression of membranebound scavenger receptors using viral vectors can modify lipid profiles and reduce the incidence of atherosclerosis. Alternatively, expression of soluble scavenger receptors can also block plaque initiation and progression. Inhibition of scavenger receptor expression using a combined gene therapy and RNA interference strategy also holds promise for long-term therapy. Here we review our current understanding of the gene delivery by viral vectors to cells and tissues in gene therapy strategies and its application to the modulation of scavenger receptor function in atherosclerosis.
\end{abstract}

\section{Introduction}

Scavenger receptors comprise a structurally diverse group of proteins [1]. Originally identified by Brown and Goldstein, they were defined by their ability to bind modified forms of low density lipoprotein (LDL) including acetylated LDL (AcLDL) and oxidized LDL (OxLDL) and were thus implicated as key regulators in initiation and progression of atherosclerosis [2]. This family of proteins has expanded to include eight different classes of membrane and soluble proteins (Class A, B, C, D, E, F, G, and H) encoded by distinct and unrelated genes [3]. Scavenger receptor classes are grouped by the presence of shared structural domains; however there is great structural diversity between the different classes. Despite this lack of sequence similarity or identity, all scavenger receptors retain the capacity to bind modified lipid particles in addition to a diverse range of polyanionic ligands of host-derived or exogenous origins, for example, pathogens $[4,5]$.

\section{Genetics of Scavenger Receptors}

Class A scavenger receptors comprise at least four related genes: scavenger receptor A (SR-A), macrophage receptor with collagenous structure (MARCO), scavenger receptor with C-type lectin (SRCL), and scavenger receptor A-5 (SCARA5) [6-10]. The human and murine SR-A genes are located on chromosome 8 and can be transcribed to produce three (SR-AI/II/III) or two SR-A splice variants, respectively [11]. SR-AI/II is largely found on macrophages 
but are also present on endothelial cells and vascular smooth muscle cells (VSMCs). Oxidative stress, OxLDL, macrophage colony-stimulating factor (M-CSF), and phorbol esters can elevate SR-A levels [12-15]. SR-A is postulated to be proatherogenic due to its ability to mediate uptake of OxLDL in macrophages $[16,17]$. Deficiency of SR-AI and SR-AII not only led to the formation of smaller atherosclerotic lesions, but also to a reduction of macrophage adhesion and increased susceptibility to bacteria and viruses [18, 19]. MARCO is located on human chromosome 2 or mouse chromosome 1 [20], and the gene product is expressed largely on macrophages and on splenic dendritic cells to a lower extent $[9,21]$. MARCO is implicated in host defense and pathogen clearance since binding to dead or apoptotic cells, bacteria, and lipopolysaccharides elevates MARCO levels [22, 23]. When challenged with Streptococcus pneumoniae, wild type mice could clear the infection whereas the ability was impaired in $\mathrm{MARCO}^{-/-}$mice, demonstrating the role of MARCO in the innate immune response against pathogens [24]. MARCO expression in human alveolar macrophages also plays a crucial role in the innate immunity against bacteria [25]. Human and murine SRCL genes are both located on chromosome 18 and can generate at least 2 splice variants in humans. In contrast to the other Class A gene products, SRCL is detected on endothelial cells but not macrophages [26] and may be involved in the innate immune response against fungal infections [27]. SCARA5 is located on mouse chromosome 14: the resulting gene product is detected on epithelial cells but not macrophages [7] and may play unique role(s) in the innate immune system and atherosclerosis [28].

Class B contains at least four members: CD36, SR-B (also known as CLA-1 in humans), LIMPII-related genes, and CD163. CD36 is located on human chromosome 7 or murine chromosome 5 [29] and its expression is mostly limited to cells of lymphoid and hematopoietic lineages including leukocytes, platelets, endothelial cells, adipocytes, VSMCs, and some epithelial cells; its levels are highest in macrophages $[30,31]$. Double knockout SR-A ${ }^{-/-} / \mathrm{CD} 36^{-/-}$mice show increased foam cell formation and atherosclerotic lesion size, suggesting that CD36 acts as a major cellular receptor for OxLDL $[16,32,33]$. However, a different study using a triple knockout SR-A ${ }^{-/-} / \mathrm{CD}^{-/-} \mathrm{ApoE}^{-/-}$mouse demonstrated no change in atherosclerotic lesion size but decreased levels of various inflammatory gene products; $\sim 30 \%$ decrease in macrophage apoptosis and $\sim 50 \%$ decrease in plaque necrosis suggested delayed progression towards advanced, unstable atherosclerotic lesions [34]. In the nematode $C$. elegans, the CD36 orthologue (C03F11.3) mediates host defense against fungal pathogens [35]. Higher levels of a soluble form of CD36 are biomarkers of insulin resistance and plaque instability in patients with diabetes and internal carotid stenoses, respectively [36, 37]. CD36-deficient mice when challenged with pathogens were significantly more susceptible to the infections [38, 39]. Humans expressing CD36 allelic variants were also more susceptible to malaria [40] demonstrating its important role in the immune system. SR-BI (SCARB1) is located on human chromosome 12 or mouse chromosome 5 [41] and encodes two protein isoforms
(SR-BI/II) [42] in monocytes, macrophages, hepatocytes, and adipose and steroidogenic tissues [43]. SR-BI expression is elevated by either PPAR $\alpha$, PPAR $\gamma$, testosterone, PUFA, or TSA [44-47] and downregulated by either OxLDL, TNF- $\alpha$, IL-1, or lipopolysaccharides $[48,49]$. SR-B1 is a receptor for hepatitis $\mathrm{C}$ virus, Plasmodium, and mycobacteria pathogens [50-52]. In contrast to other scavenger receptors, SR-BI could provide protective function(s) against atherosclerosis by increasing the macrophage-based cholesterol efflux into HDL particles followed by liver HDL clearance and excretion $[47,53-56]$. LIMPII is located on human chromosome 4 or mouse chromosome 5 and has a similar expression profile to SR-BI [31]. CD163 (M130) [57] is located in human chromosome 12 [58] and expressed in monocytes and macrophages in both membrane-bound and soluble forms [59] where it plays an important role in the regulation of anti-inflammatory responses, pathogen recognition, and atheroprotection probably through elevation in expression of heme oxygenase and in removing free hemoglobin [60-63]. Patients with hematological, inflammatory, and lysosomal storage diseases have also a high level of soluble CD163, and it may thus serve as a biomarker for such conditions $[64,65]$.

Class C comprises of just one scavenger receptor, dSRC1 which has only been so far identified in the fruit fly Drosophila melanogaster. dSR-C1 is a pattern recognition receptor for bacteria expressed in hemocytes and macrophages during fly embryonic development [66]. It can recognize bacteria and may play a role in the innate immune system of the insect [67].

Class D comprises the CD68 and lysosomal membrane glycoprotein (Lamp) gene products. CD68 is located on human chromosome 17 and the murine orthologue (also called macrosialin) is located on murine chromosome 11 [68]. Macrophages, Langerhans cells, dendritic cells, and osteoclasts express CD68 in pattern similar to the class B gene products [69]. The expression levels can be elevated by OxLDL, GM-CSF, and phorbol ester but inhibited by TNF- $\alpha$ and lipopolysaccharides [70-72]. Macrosialin levels are also observed to be increased by a proatherogenic diet: OxLDL and macrosialin were both found in macrophages within atherosclerotic plaques from ApoE-deficient mice [73]. Macrosialin has been identified as a receptor for OxLDL [74-76] although this view has been challenged [77]. The three Lamp genes (1, 2, and 3) are located in human chromosome $13, \mathrm{X}$, and 3 or murine chromosomes $8, \mathrm{X}$, and 16, respectively [78]. Lamp-1 and -2 are constitutively and widely expressed whereas Lamp-3 is elevated during dendritic cell maturation implying a functional link to the immune system [79].

Class E comprises of just one member: the lectinlike oxidized low density lipoprotein receptor 1 (LOX-1). LOX-1 (OLR1) is located on human chromosome 12 [80] or mouse chromosome 6 and is expressed on endothelial cells, macrophages, smooth muscle cells, and platelets [81, 82]. The resting levels are relatively low but elevated by proinflammatory stimuli including OxLDL, inflammatory cytokines, for example, TNF- $\alpha$, shear stress, oxidative stress, phorbol ester, endothelin-1, and angiotensin II [83-87]. 
A splice variant (LOXIN) conferred protection against the proatherogenic LOX-1 effects by forming inactive heterodimers with LOX-1 and blocking OxLDL-induced apoptosis in macrophages [88, 89]. A human LOX-1 allelic polymorphism $(\mathrm{K} 167 \mathrm{~N})$ is postulated to increase the risk of CVD in a patient cohort [90]. However, further investigations into the associations between the LOX-1-K167N polymorphism, myocardial infarction (MI) and cardiovascular disease (CVD) have produced conflicting data [91, 92] suggesting that this polymorphism has no effects on CVD incidence [93]. The expression profile of a soluble LOX1 species was elevated in obese postmenopausal women [94], and it is a biomarker for type 2 diabetes mellitus and atherogenesis [95-97]. In dendritic cells, LOX-1 can act as a receptor that mediates the uptake of antigens [98]. Overexpression of LOX-1 in CHO cells led to bacterial binding and uptake [99]. Macrophage LOX-1 depletion inhibits foam cell formation suggesting a role in atherosclerotic plaque initiation and progression [100]. Importantly, the incidence of atherosclerotic plaques is significantly lowered in LOX-1deficient mice [101].

Class $\mathrm{F}$ consists of the SREC gene products (scavenger receptors expressed by endothelial cells) which are expressed on mammalian endothelial cells and macrophages [102] and also in nematodes [103]. The SREC-I gene is related to the EGF precursor gene [104] and is located on human chromosome 17 but the murine orthologue called SCARF-1 is located on mouse chromosome 11. In humans, alternative splicing gives rise to at least five different membranebound and soluble protein isoforms [105]. SREC-I levels are elevated by lipopolysaccharides [102] and repressed by cytokines such as IL- $1 \alpha$, IL- $1 \beta$, and TNF- $\alpha$ [105]. In humans, another gene called SREC-II that displays $\sim 35 \%$ similarity to SREC-I is located on chromosome $22[104,106]$. Murine SREC-II is located on chromosome 16 [107]. In C. elegans, a SREC-like gene product called CED-1 is implicated in the engulfment of apoptotic cells during animal development and immune defense against pathogens [35, 108, 109]. SREC-I is a receptor for Ac-LDL [102].

The chemokine ligand CXCL16 is a class G scavenger receptor that binds phosphatidylserine and oxidized lipoprotein (SR-PSOX). SR-PSOX is located on human chromosome 17 and mouse chromosome 11. SR-PSOX is highly expressed on macrophages, smooth muscle cells, dendritic cells, kidney and B cells with lower levels detected on the endothelium, and T cells [110-119]. Monocyte SR-PSOX expression is increased by TNF- $\alpha$, IFN- $\gamma$, LPS, or OxLDL stimulation $[113,115,120]$. In addition to SR-PSOX links to atherosclerosis $[120,121]$ where the molecule was induced in vitro and in vivo by atherosclerosis-promoting inflammatory signals [122], it is also involved in acute and adaptive experimental autoimmune encephalomyelitis [123], CD8+ T cell recruitment during inflammatory valvular heart disease [124], and bacterial phagocytosis [116]. A soluble form of SR-PSOX functions as an activated T cell and NK cellrecruiting chemokine $[112,125]$ and is a biomarker for acute coronary syndrome [126].

Class H scavenger receptors consist of Fasciclin, EGF-like, lamin type EGF-like and link domain-containing scavenger receptor-1 (FEEL-1), also known as stabilin-1 or CLEVER-1 [127] and FEEL-2 (stabilin-2) a paralogous protein with 39\% sequence identity to FEEL-1 [128-130]. The FEEL-1 gene (STAB1) is located on human chromosome 3 and mouse chromosome 14, and the FEEL-2 gene (STAB2) is located on human chromosome 12 and murine chromosome 10. Expression levels of both FEEL-1 and -2 are high in the liver and lymph nodes. FEEL-1 is expressed on monocytes, macrophages, and endothelial cells whereas FEEL-2 expression was not detected on these cell types in humans [128]. FEEL-2 was found to be expressed in sinusoidal endothelial cells in the liver, lymph node, spleen, and bone marrow in mice as well as heart valve mesenchyme, brain, eyes, and kidneys [131], with expression levels being increased during development in the zebrafish Danio rerio [132]. FEEL-1 is known to undergo alternate splicing to yield an isoform lacking exon 27 [130]. Sorting nexin 17 (SNX17) is required for maximum cell surface expression of FEEL-1 [133]. Knockdown of SNX17 leads to a dramatic reduction in cell surface expression, due to increased degradation of the receptor.

\section{Scavenger Receptor Structure and Function}

Scavenger receptors are present on different tissues ranging between macrophages, monocytes, platelets, endothelial, smooth muscle, and epithelial cells. In addition to vascular tissues, they are also detected in adipose and steroidogenic tissues (Table 1) [9, 13, 82, 110, 134-137]. A general mechanism underlying scavenger receptor levels is the elevation of gene expression in response to ligand binding to cell surface receptors, thus generating a positive feedback loop that mediates enhanced ligand clearance and/or accumulation $[138,139]$. This is in contrast to other membrane-bound receptors such as the low-density lipoprotein receptor (LDL$\mathrm{R})$ that is downregulated in response to binding LDL ligand, thus exhibiting a negative feedback mechanism [140].

Scavenger receptors are generally classified as membranebound proteins that bind modified LDL particles and other polyanionic ligands. These include AcLDL, OxLDL, Gram-positive and Gram-negative bacteria, apoptotic cells, $\beta$-amyloid fibrils, and advanced glycation end products (AGE) (Table 1) $[4,5]$. Following ligand binding, scavenger receptors can mediate intracellular signaling and/or ligand internalization. A generic model for such regulation is outlined in Figure 1. Although there is little structural homology between the ligand-binding domains of scavenger receptors from different classes, mutagenesis studies have revealed some conserved characteristics. These include positively charged arginine or lysine clusters in the ligandbinding domain of either the LOX-1 scavenger receptor [141] or CD36 [142], respectively. Such amino acid clusters appear to be required to mediate electrostatic interactions with the predominantly negatively charged modified lipid particle or polyanionic ligand although other noncharged hydrophilic residues may also be involved [141]. The avidity of ligand binding is also enhanced through the formation of scavenger receptor dimers [143], trimers [144], and higherorder oligomers [145]. 
TABLE 1: The major scavenger receptor ligands and expression profiles.

\begin{tabular}{|c|c|c|c|c|}
\hline Class & $\begin{array}{l}\text { Scavenger } \\
\text { receptor }\end{array}$ & Ligands & Expression profile & Involvement in CVD? \\
\hline A & SR-A & $\begin{array}{l}\text { AcLDL, OxLDL, } \beta \text {-amyloid, } \\
\text { molecular chaperones, ECM, AGE, } \\
\text { apoptotic cells, activated B-cell, } \\
\text { bacteria }\end{array}$ & $\begin{array}{l}\text { Macrophages, mast, dendritic, } \\
\text { endothelial and smooth muscle cells }\end{array}$ & $\begin{array}{l}\text { Yes_-involved in OxLDL uptake by } \\
\text { macrophages leading to foam cell } \\
\text { formation }\end{array}$ \\
\hline A & MARCO & $\begin{array}{l}\text { AcLDL, OxLDL, apoptotic cells, B } \\
\text { cells, bacteria }\end{array}$ & Macrophages, dendritic cells & No \\
\hline B & SR-B & HDL, LDL, OxLDL, apoptotic cells & $\begin{array}{l}\text { Monocytes/macrophages, } \\
\text { hepatocytes and adipocytes }\end{array}$ & $\begin{array}{l}\text { Reduces atherosclerosis through } \\
\text { reverse cholesterol transport of } \\
\text { HDL }\end{array}$ \\
\hline B & CD36 & $\begin{array}{l}\text { AcLDL, OxLDL, HDL, LDL, VLDL, } \\
\beta \text {-amyloid, AGE, apoptotic cells }\end{array}$ & $\begin{array}{l}\text { Macrophages, platelets, adipocytes, } \\
\text { epithelial and endothelial cells }\end{array}$ & $\begin{array}{l}\text { Yes-OxLDL uptake into } \\
\text { macrophages leading to foam cell } \\
\text { formation }\end{array}$ \\
\hline $\mathrm{E}$ & LOX-1 & $\begin{array}{l}\text { OxLDL, molecular chaperones, } \\
\text { ECM, AGE, apoptotic cells, } \\
\text { activated platelets, bacteria }\end{array}$ & $\begin{array}{l}\text { Endothelial and smooth muscle } \\
\text { cells, macrophages, and platelets }\end{array}$ & $\begin{array}{l}\text { Yes-OxLDL uptake in endothelial } \\
\text { cells, leads to endothelial } \\
\text { dysfunction }\end{array}$ \\
\hline $\mathrm{F}$ & SRECI/II & $\begin{array}{l}\text { AcLDL, OxLDL, molecular } \\
\text { chaperones, apoptotic cells }\end{array}$ & Endothelial cells and macrophages & Low levels of AcLDL uptake \\
\hline G & SR-PSOX & OxLDL and bacteria & $\begin{array}{l}\text { Macrophages, smooth muscle, } \\
\text { dendritic, endothelial cells, and B- } \\
\text { and T cells. }\end{array}$ & $\begin{array}{l}\text { Yes-involved in OxLDL uptake in } \\
\text { macrophages }\end{array}$ \\
\hline $\mathrm{H}$ & FEEL-I/II & $\begin{array}{l}\text { AcLDL, molecular chaperones, } \\
\text { ECM, AGE, bacteria }\end{array}$ & $\begin{array}{l}\text { Monocytes/macrophages, } \\
\text { endothelial cell }\end{array}$ & No known link \\
\hline
\end{tabular}

SR-A: scavenger receptor class A, AcLDL: acetylated low density lipoprotein, OxLDL: oxidised low density lipoprotein, ECM: extracellular matrix, AGE: advanced glycation end products, MARCO: macrophage receptor with collagenous structure, HDL: high density lipoprotein, LDL: low density lipoprotein, VLDL: very low density lipoprotein, LOX-1: lectin-like oxidized low density lipoprotein receptor-1, FEEL-I/II: fasciclin, epidermal growth factor (EGF)-like, laminin-type EGF-like, and link domain-containing scavenger receptor-1.

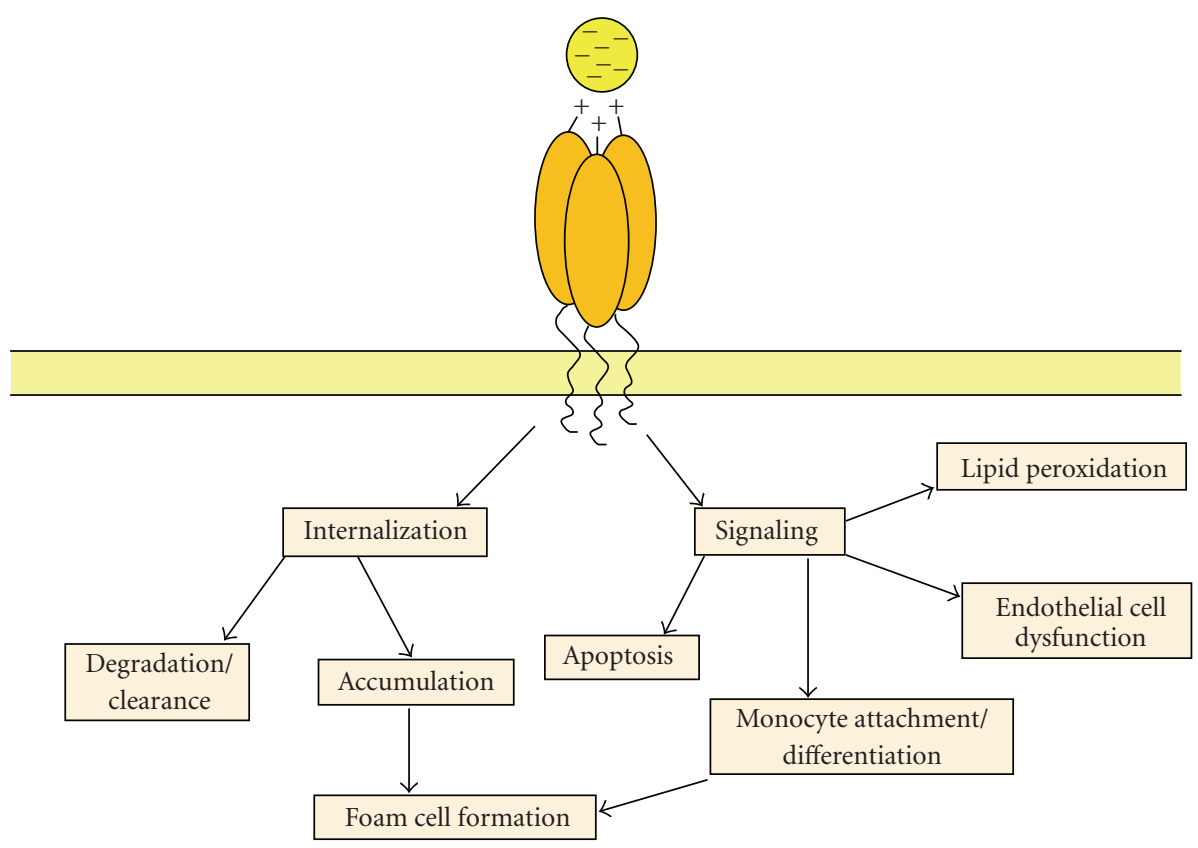

FIGURE 1: A generic model for scavenger receptor-mediated ligand binding, internalization, and signal cascade activation. Scavenger receptors bind negatively charged ligands through clusters of conserved positively charged residues. Ligands are internalized by scavenger receptors using a range of different clathrin-dependent and independent pathways. Ligands can be degraded or accumulate. Ligand binding can activate signaling cascades leading to diverse cellular functions including lipid peroxidation, apoptosis, endothelial cell dysfunction, and monocyte attachment and differentiation leading to foam cell formation. 
Scavenger receptor-ligand complexes can undergo receptor-mediated endocytosis, trafficking through the endosome-lysosome system leading to degradation or accumulation of ligand. Different mechanisms of endocytosis have been postulated for the individual classes of scavenger receptors including clathrin-dependent [146], clathrin-independent [147], and lipid raft-mediated [148] events. This diversity in scavenger receptor endocytosis is not surprising considering the sequence diversity and different endocytic motifs within the cytoplasmic domains of the different scavenger receptors [146, 147]. Following endocytosis and delivery to endosomes, it is likely that many scavenger receptors are recycled back to the plasma membrane where they can mediate further ligand binding, clearance, or accumulation.

Ligand binding to scavenger receptors activates intracellular signaling cascades leading to diverse physiological outputs including apoptosis, endothelial cell dysfunction, and lipid peroxidation. One aspect of scavenger receptor activation is monocyte infiltration and differentiation leading to foam cell formation, a key event in atherosclerotic plaque initiation and progression. For example, activation of the Class B CD36 scavenger receptor is linked to phosphorylation and activation of c-Src and MAP kinase pathway thus triggering macrophage differentiation into foam cells [149]. Another model is the LOX-1 scavenger receptor where ligand binding stimulates reactive oxygen species (ROS) production, both MAPK and NF- $\kappa$ B activation leading to increased expression of different adhesion gene products. Such elevated expression in endothelium can enable monocyte infiltration, ultimately leading to monocyte differentiation and foam cell formation.

\section{Current Atherosclerosis Therapies}

Atherosclerosis is a leading cause of mortality in Europe and Western countries [150]. The subversion of human vascular function by atherosclerosis can lead to cardiovascular morbidity and mortality, including ischemic stroke, ischemic heart disease, myocardial infarction, and peripheral arterial disease. The causes of atherosclerosis are multifactorial, meaning that single intervention therapy has as yet not succeeded in major reductions in disease incidence. Ongoing large investments by many countries worldwide are directed towards the prevention of cardiovascular disease by modifying environmental risk factors. Within the United Kingdom alone, a vascular risk and assessment program is currently in its initial roll out phase, aiming to tackle modifiable risk factors in a healthy 40-74-year age group (http://www.dh.gov.uk/en/Publicationsandstatistics/ Publications/PublicationsPolicyAndGuidance/DH_083822). Despite economic modeling predicting a relatively large annual cost (US\$60 million), this approach is predicted to prevent approximately 9500 cases of myocardial infraction and strokes annually. This would thus also be cost effective in the long term. (http:// www.dh.gov.uk/en/Publicationsandstatistics/Publications/ PublicationsPolicyAndGuidance/DH_085869).

Pharmacological agents have only been partially successful in attenuating the clinical manifestations of atherosclerosis with the most dramatic effects achieved by statins, which inhibit 3-hydroxy-3-methyl glutaryl coenzyme A (HMG-CoA) reductase. Statin therapy has reduced the 5-year incidence of major cardiovascular events by $\sim 20 \%$ with each millimole per liter reduction in levels of cholesterol in LDL particles [151]. It is thought that statins exert their effect through inhibiting the rate-limiting step in cholesterol biosynthesis, which in turn leads to elevation of LDL receptor expression. However there is much debate over the importance of additional lipid-independent modes of action including anti-inflammatory effects [152]. Clinical treatment of established atherosclerotic plaques is becoming more technologically advanced, with routine intra-arterial catheterization and angioplasty of damaged arterial blood vessels. Stents are commonly used, and new technologies, such as drug-eluting stents, raise exciting possibilities for potential gene therapy as well. Evaluation of a patient's genetic background in atherosclerotic plaque initiation and progression could be essential to provide major disease alleviation by combining intervention, medication, and lifestyle modification in tailored therapies. Targeting the scavenger receptor gene products that mediate the response to and/or uptake of modified LDL holds great promise in the prevention of cardiovascular disease.

\section{Gene Therapy}

Gene therapy is the process of ameliorating or curing a genetic disease by introducing a fragment of genetic material into diseased or dysfunctional cells. Viral or nonviral vectors are the vehicles used to transfer and express specific genes within a target cell and thus used to correct genetic disorders. The idea of using genetic material to treat human diseases gained prominence in 1960s [153], and in 1973, the first attempt used a wild-type human papilloma virus in attempting to correct hyperargininaemia [154] but this was unsuccessful. Even though subsequent gene therapy attempts were controversial [155], this area of biomedicine obtained the first signs of success by tackling adenosine deaminasedeficient severe combined immunodeficiency (ADA-SCID) [156]. The first ADA-SCID patient treated successfully using this technology has subsequently led a relatively normal lifestyle with amelioration of the disease symptoms [157]. By 2007, >1300 gene therapy clinical trials have taken place of which the majority of trials (67\%) aimed at cancer treatment; gene therapy of cardiovascular diseases formed the second largest cohort of clinical trials (9\%). The number of clinical gene therapy trials currently exceeds 1500 (http://www.wiley.co.uk/genmed/clinical/) and may well live up to the expectations of becoming the "twenty-first century medicine" to deliver personalized healthcare [158].

Nevertheless, successful clinical gene therapy has encountered numerous problems. The two major problems that usually hamper gene therapy efficacy are (1) immune response(s) against the protein products of the transgene or the vector and (2) insertional mutagenesis by the viral vector. Since viral vectors are based on pathogenic viruses, they can induce immune responses [159-161], and much of the human population may have preexisting immunity 
against human viruses. Depending on the conditions used, this immunogenicity can lead to adverse effects. During one study on adenoviral-mediated treatment of ornithine transcarbamylase (OTC) deficiency, one of the eighteen subjects died as a result of an exacerbated immune response to the injected adenoviral vector carrying an E1-E14 deletion $[162,163]$. Leukemia induction was also noticed in a mouse model following gene transfer using retroviral vectors caused by vector integration into the ecotropic viral integration Site-1 (Evi1) [164]. Two different gene therapy studies on X-linked SCID (SCID-X1) using retroviral vector integration resulted in leukemia induction in four out of nine subjects with one death $[165,166]$ and leukemia in one out of ten subjects $[167,168]$. Retroviruses and lentiviruses undergo obligatory integration of the provirus into the host genome as a part of the life cycle, and this may lead to activation or increased expression of nearby host genes $[169,170]$. In the case of retro- and lentiviral vectors, the promoter enhancer elements located in the viral termini appear responsible for this altered host gene expression profile $[171,172]$.

In contrast, although the viral termini located within adeno-associated viruses $[173,174]$ and adenoviruses [175177] have enhancer and promoter activities, insertional mutagenesis caused by vectors based on these viruses have not as yet been reported. However, even in the case of adenoviral vectors which have been perceived as nonintegrating vectors, there are instances of viral integration into the chromosomal DNA close to or within host genes and instances of genetic mutations and rearrangements [178, 179]. A slightly higher percentage of adeno-associated viral vector DNA $[180,181]$ integrated into genes causing chromosomal deletions and translocation [182-184]. Despite the lack of adverse affects in cystic fibrosis gene therapy trials, the effects caused by administration of different viral and nonviral gene therapy vectors were not sufficient to cause regression of clinical symptoms; natural lung adaptation to alien particle administration may have also hindered patient gene transfer [185]. However, successful gene therapy in the treatment of ADA-SCID and lack of adverse effects [186] holds much promise for further work.

\section{Gene Therapy Vectors}

Gene therapy vectors are genetic vehicles used to transfer DNA sequences or specific genes from the laboratory bench into the diseased cells or tissues and are viral or nonviral in origin. Viruses are well adapted to infect cells or tissues, and these adaptations have been utilized to generate viral vectors for gene therapy. Such viral vectors constitute $66 \%$ of clinical gene therapy trials worldwide (http://www.wiley.co.uk/genmed/clinical/). Both viral and nonviral vectors have their advantages and disadvantages in gene therapy (summarized in Table 2).

6.1. Nonviral Gene Therapy Vectors. Nonviral gene delivery systems utilize physical force or chemical methods to deliver the genetic material to the cell. Major nonviral vectors used in gene therapy include circular plasmid or linear DNA complexed with nanoparticles $[187,188]$ or liposomes (cationic lipid-DNA complex) [189, 190]. Plasmid DNA can be transferred into the cells using a gene gun [191] where the DNA is bound to high density particles like gold and transferred at high velocities into the cell [192] or by electroporation [193], using transposable elements [194] or DNA:RNA oligonucleotide hybrids [195]. Even though nonviral gene therapy methods are used in clinical trials [196] they usually exhibit lower gene transfer efficiency and transient gene expression [197-200]. This is especially true when both viral and nonviral systems were compared simultaneously [201]; the immune response [202-205] may also limit the therapeutic capability of nonviral gene therapy.

6.2. Viral Gene Therapy Vectors. Since viruses are well adapted to evade the host immune responses and to deliver the genetic material into the host cells, gene therapy vectors based on viruses have been more effective so far and currently account for two-thirds of all gene therapy clinical trials worldwide (http://www.wiley.co.uk/genmed/clinical/). Barring the use of vectors in suicide gene therapy [206], viral gene delivery systems utilize viral vectors with defective replication capabilities. The coding region of the viral genome is replaced by foreign genetic material, leaving only the cis-acting elements essential for viral packaging and/or integrating into the host genome on the vector. Producer cell lines can provide the essential viral gene products either totally by themselves or by the assistance of other systems, which are used to generate nonreplicating viral vectors [207]. Currently, vectors based on adeno-associated viruses, retroviruses, and adenoviruses form the majority of the viral vectors used as gene delivery systems.

6.2.1. Adeno-Associated Viral (AAV) Vectors. Adenoassociated viruses belong to the Parvoviridae family which have a nonenveloped icosahedral capsid containing a single-stranded DNA genome. This viral DNA has cis-acting palindromic inverted terminal repeats at each end which form hairpins that are essential for DNA replication and packaging [208]. Most of the current AAV-based gene therapy vectors are derived from AAV-2 subtype. This virus is dependent on coexpression of an adenovirus or herpes helper virus for gene products essential for lytic productive infection where the genome is replicated, and virions are produced. In the absence of the helper virus, AAV-2 undergoes site-specific integration to establish a latent state. The provision in trans of the AAV Rep (regulatory) and Cap (structural capsid) genes together with the adenoviral early viral genes (provided by a helper virus) is needed to generate AAV vectors for gene therapy $[158,207,209]$. Despite the smaller AAV transgene capacity [210] and the preexisting immunity against AAV [211], these vectors have been used successfully in animal models of retinal disorders [212, 213], cystic fibrosis [214, 215], hemophilia B [216, 217], muscular dystrophy, and DNA vaccination [218]. They are currently used in human clinical gene therapy trials [219].

6.2.2. Adenoviral Vectors. Adenoviruses belong to the Adenoviridae family and contain nonenveloped icosahedral capsid with a double-stranded DNA genome. A cis-acting inverted 
terminal repeat is present at each end of the DNA and a packaging signal at the $5^{\prime}$ terminus [220]. Some of the early adenoviral genes (e.g., E1) have transforming and transactivating functions and were thus replaced by inserted DNA sequences or the gene of interest in the first generation adenoviral vectors. However, this did not prevent low level expression of other adenoviral gene products, including those with immunogenic and toxic properties causing rapid clearance from host in vivo [221, 222]. To both avoid this adaptive immune response and to increase viral transgene capacity, high capacity adenoviral vectors (HC-AdV) were developed where the only viral elements present are the cis-acting ITRs and packaging signal with viral gene products needed for replication provided in trans by a packaging-deficient helper virus [223]. Even though the innate immunity against adenoviral capsid would still elicit an immune response [161], this may be circumnavigated either by using adenoviral vectors of different serotypes [224] or by modifications with synthetic polymers [225]. The large cloning capacity of $36 \mathrm{~kb}$ and the longevity of transgene expression [226-228] in tissues with low cellular turnover hint at potentially successful gene therapy. Adenoviral vectors have been used successfully in rodent, canine, and primate models of cardiovascular diseases [229, 230], muscular dystrophy [231, 232], glycogen storage diseases [233], hemophilia [234], cancer [235-237], retinal disorders [238], and DNA vaccination studies [239]. Adenoviral vectors comprise the largest group of the largest group of vectors $(24 \%)$ used in clinical gene therapy trials (http://www.wiley.co.uk/genmed/clinical/) [240, 241].

6.2.3. Retro- and Lentiviral Vectors. Retroviruses are enveloped single-stranded RNA viruses where the RNA genome is reverse transcribed into a DNA provirus which then integrates into the host chromosomal DNA during its life cycle. The viral genome is flanked by long terminal repeats (LTRs) which along with the packaging signal and a truncated gag gene comprising the cis-acting elements essential for functionality. Retroviral genes encoding the capsid proteins, the viral protease, the reverse transcriptase, and the integrase are supplied in trans by transient transfection of plasmids to generate an assembled virus with gene delivery capability [242-244]. Lentiviruses are more complex, regulatory and accessory genes, and have the capability to infect dividing and nondividing cells in contrast to retroviruses which can only infect dividing cells. Functional lentiviral vectors also need expression of the Rev (cytoplasmic transport of the RNA) and the Tat (viral promoter transactivator) viral gene products.

One biosaftey issue when using viral gene therapy is that extensive genetic recombination of the viral and host genomes could generate replication-competent viruses. Whilst the generation of replication-competent adenoviruses may cause only relatively mild health problems, this is likely to be dangerous if replication-competent lentiviruses are generated. To reduce this risk during the packaging process in vitro using cultured cell lines, gag and pol (with additional tat and rev for lentiviral vectors) and env are present on different plasmids. A further biosafety improvement is removal of the U3 region (enhancer-promoter) of the viral LTR to generate self-inactivating (SIN) vectors [245]. Since reverse transcription means that both the $5^{\prime}$ and 3 ' $\mathrm{U} 3$ regions of the provirus DNA are transcribed, this deletion would abrogate synthesis of a complete RNA viral genome packaged into virions. One feature of the retrovirus life cycle is integration of the provirus into the host genome causing persistent gene expression [246]. Gene therapy using retro- or lentiviral vectors has been successfully used in the gene therapy experiments for treating Duchenne muscular dystrophy [247], hemophilia [248], Fanconi anemia [249], diseases of the central nervous system [250], DNA vaccination [251], X-linked SCID, adenosine deaminase SCID, and chronic granulomatous disease $[168,252]$. These successes of these studies in a combination of rodent, canine, primate models have now led to $\sim 21 \%$ of current human clinical trials for gene therapy.

\section{Scavenger Receptor Gene Therapy}

Even in the late 1980s, cardiovascular dysfunction was a major focus of gene therapy trials. In a rabbit model of homozygous familial hypercholesterolemia, a retroviral LTR promoter was used to overexpress human LDL-R in fibroblasts [253]. Elsewhere, retroviral vectors containing $\mathrm{LacZ}$ encoding $\beta$-galactosidase were used for ex vivo transduction of canine and porcine endothelial cells: $\beta$-galactosidase expression could be detected after surgical implantation into canine and porcine models [254, 255]. Currently, the proportion of clinical gene therapy trials for cancer $(65 \%)$ is followed by the second largest trial group on cardiovascular disease (9\%) (http://www.wiley.co.uk/genmed/clinical/).

As mentioned earlier, scavenger receptor function is associated with both healthy and pathophysiological processes ranging between homeostasis, apoptotic cell clearance, diabetic necropathy, age-induced cardiomyopathy, and antigen cross-presentation in Alzheimer's disease [256-260]. Importantly scavenger receptor function is heavily implicated in atherosclerotic plaque initiation and progression [261], making this diverse protein supergroup [1] an attractive target for gene therapy (Figure 3). Currently, the majority of scavenger receptor gene therapy studies have utilized adenoviral vectors (Table 3 ).

7.1. LOX-1 Gene Therapy. A mouse knockout model lacking LOX-1 suggested that this was a key contributory factor in driving lipid accumulation in vascular tissues [101], raising the question as to whether these properties could be manipulated using gene therapy. A first-generation adenoviral vector expressing human LOX-1 was used to successfully express LOX-1 transiently in vascular smooth muscle cells (VSMCs) and other cells [262]. A first-generation first-generation adenoviral vector was used to provide ectopic expression of LOX-1 in hepatic tissues of the ApoE-deficient mice, leading to increased OxLDL excretion, reduction in plasma OxLDL, and complete loss of atherosclerotic plaque initiation and progression [263]. In addition, oxidative stress and inflammatory responses were reduced in the mice infected with adenovirus LOX-1. Nevertheless, OxLDL levels returned to 
TABLE 2: The advantages and disadvantages of the major gene therapy vectors currently used.

\begin{tabular}{llll}
\hline $\begin{array}{l}\text { Gene therapy } \\
\text { vector }\end{array}$ & Genetic material & Advantages & Disadvantages \\
\hline $\begin{array}{l}\text { Nonviral vectors } \\
\begin{array}{l}\text { Retro-/lentiviral } \\
\text { vectors }\end{array}\end{array}$ & Rainly DNA & Large transgene capacity, biosafety & $\begin{array}{l}\text { Low efficiency, immune response (cationic } \\
\text { lipids and polymers), toxicity }\end{array}$ \\
\hline $\begin{array}{l}\text { Adeno- } \\
\text { associated viral } \\
\text { vectors }\end{array}$ & DNA & $\begin{array}{l}\text { Stable integration, lack of immune response, } \\
\text { up to 10 kb cloning capacity }\end{array}$ & $\begin{array}{l}\text { Insertional mutagenesis following } \\
\text { integration is higher }\end{array}$ \\
\hline $\begin{array}{l}\text { First-generation } \\
\text { adenoviral } \\
\text { vectors }\end{array}$ & DNA & $\begin{array}{l}\text { Long-term expression, site-specific } \\
\text { integration }\end{array}$ & Immune response, small transgene capacity \\
$\begin{array}{l}\text { High capacity } \\
\text { adenoviral } \\
\text { vectors }\end{array}$ & DNA & High titer, up to $8 \mathrm{~kb}$ of cloning capacity & $\begin{array}{l}\text { Immune response and toxicity leading to } \\
\text { shortened duration of transgene expression } \\
\text { in vivo }\end{array}$ \\
\hline
\end{tabular}

control baseline levels 3 weeks after hepatic LOX-1 overexpression. This profile of gene expression correlates with the expected duration of transgene expression using first generation adenoviral vectors [221]. This raises the question whether more sustained long-term LOX-1 expression using stable ectopic expression systems or integrating viruses would be a better strategy to inhibit atherosclerosis.

7.2. SR-A Gene Therapy. A retroviral vector with a bovine SR-AII cDNA transgene was used to show increased lipid accumulation, foam cell formation, and predisposition to apoptosis in fibroblasts and smooth muscle cell lines [264]. This suggests that manipulation of SR-A levels might be advantageous in hindering proatherogenic responses in vascular tissues [264]. A hybrid gene containing the human CD68 promoter upstream of truncated human SR-AI encoding the extracellular domain alone and expressed using an adenoviral vector inhibited degradation of AcLDL and OxLDL particles and subsequent foam cell formation [265]. One conclusion is that soluble SR-AI binds to modified LDL particles and sequesters such ligands away from the wild-type membrane-bound scavenger receptors.

Using the LDL-R knockout mouse that develops atherosclerotic lesions, overexpression of soluble human SR-AI using this adenoviral system completely blocked plaque initiation and progression [266]. However, similar to gene expression profiles for first- and second-generation adenoviral vectors, the plasma soluble SR-AI returned to control baseline levels after 4 weeks [266]. When adenoassociated viral vectors were used to express soluble SR-AI in the same mouse model, the atherosclerotic lesion area was reduced and persistence of soluble SR-AI plasma levels was observed for 6 months [267]. Expression of murine MARCO using a lentiviral vector in cultured cells suggests that quality control along the secretory pathway is essential for scavenger receptor assembly and presentation at the plasma membrane [274]. SR-A may also be a receptor for adenovirus binding and host cell entry [275], and this could be further exploited to block macrophage lipid accumulation leading to foam cell formation during atherosclerosis.
7.3. SR-BI Gene Therapy. High-density lipoprotein (HDL) particles can mediate reverse cholesterol transport, have antiatherogenic properties, and are recognized by the SRBI glycoprotein [276, 277]. Current gene therapy used first-generation adenoviral vectors to express murine SRBI. Transient hepatic expression of murine SR-BI in mice increased HDL clearance, reduction in plasma HDL levels, and increased biliary cholesterol levels [54]. These effects are either due to increased hepatic uptake of HDL and/or the increased cholesterol secretion into the bile. Similar results were obtained with the same adenoviral vector delivered into LDL-R knockout mice with reduction of both early and advanced atherosclerotic lesions [55]. One explanation is that SR-BI overexpression resulted in a reduction of all three of HDL, LDL, and VLDL levels [278]. However, in human ApoB transgenic mice, SR-BI expression from the same vector resulted in a much lesser LDL-metabolism compared to HDL metabolism [279]. A xenogenic model comprising ApoAI knockout mice and SR-BI overexpression was used to examine transplanted human HDL processing. Here, small and dense HDL particles are not cleared from the circulation but remodel in the plasma to form larger HDL particles [280]. Similar SR-BI expression in a rabbit model caused reduction in HDL levels and increased LDL levels [268]. Again, SR-BI overexpression increased biliary excretion of cholesterol [269].

HDL binding to SR-BI can activate intracellular signaling leading to increased endothelial nitric oxide synthase (eNOS) activity [281]. Coexpression of SR-BI and Apobec 1 (essential in ApoB mRNA editing, resulting in the truncated ApoB48 product) in immortalized hepatic cells using a HC-Ad vector caused reduction in ApoB levels. Using the same system on immortalized endothelial cells caused increased eNOS phosphorylation and elevated nitric oxide levels [270]. However, the amount of HDL normally absorbed by the liver from the bloodstream is relatively low [282]. SR-BI allelic polymorphisms also do not correlate with variations in plasma HDL levels [283]. More clinical gene therapy studies are desirable to fully test whether this molecule is a good candidate for alleviating atherosclerosis. 
TABLE 3: List of the main viral gene therapy experiments examining the therapeutic potential of scavenger receptors.

\begin{tabular}{|c|c|c|c|}
\hline $\begin{array}{l}\text { SR } \\
\text { used/targeted }\end{array}$ & Vector used & Outcome & References \\
\hline LOX-1 & FG AdV & $\begin{array}{l}\text { Inhibition of the progression of } \\
\text { atherosclerosis }\end{array}$ & Ishigaki et al. [263] \\
\hline Soluble SR-A1 & FG AdV & Foam cell formation inhibited & Laukkanen et al. [265] \\
\hline Soluble SR-A1 & FG AdV & Abrogation of the atherosclerotic lesion area & Jalkanen et al. [266] \\
\hline Soluble SR-A1 & AAV & Abrogation of the atherosclerotic lesion area & Jalkanen et al. [267] \\
\hline SR-B1 & FG AdV & Reduction of plasma HDL & Kozarsky et al. [54] \\
\hline SR-B1 & FG AdV & Reduction of plasma HDL & Kozarsky et al. [55] \\
\hline SR-B1 & FG AdV & Reduction of plasma HDL, increase of LDL & Tancevski et al. [268] \\
\hline SR-B1 & FG AdV & Increased biliary secretion of cholesterol & Wiersma et al. [269] \\
\hline $\begin{array}{l}\text { SR-B1 and } \\
\text { Apobec } 1\end{array}$ & HC-AdV & Reduction of Apo B levels, elevation of NO & Zhong et al. [270] \\
\hline SR-B1/CD36 & FG AdV & $\begin{array}{l}\text { SR-B1 mediated uptake of cholesterol esters } \\
\text { higher than that by CD36. However, CD36 } \\
\text { resulted in higher levels of Ox-LDL } \\
\text { degradation }\end{array}$ & de Villiers et al. [271] and Sun et al. [272] \\
\hline CD36 & FG AdV & Increased hepatic fatty acid uptake & Koonen et al. [273] \\
\hline SR-PSOX & LV & Decreased foam cell formation & Zhang et al. [120] \\
\hline
\end{tabular}

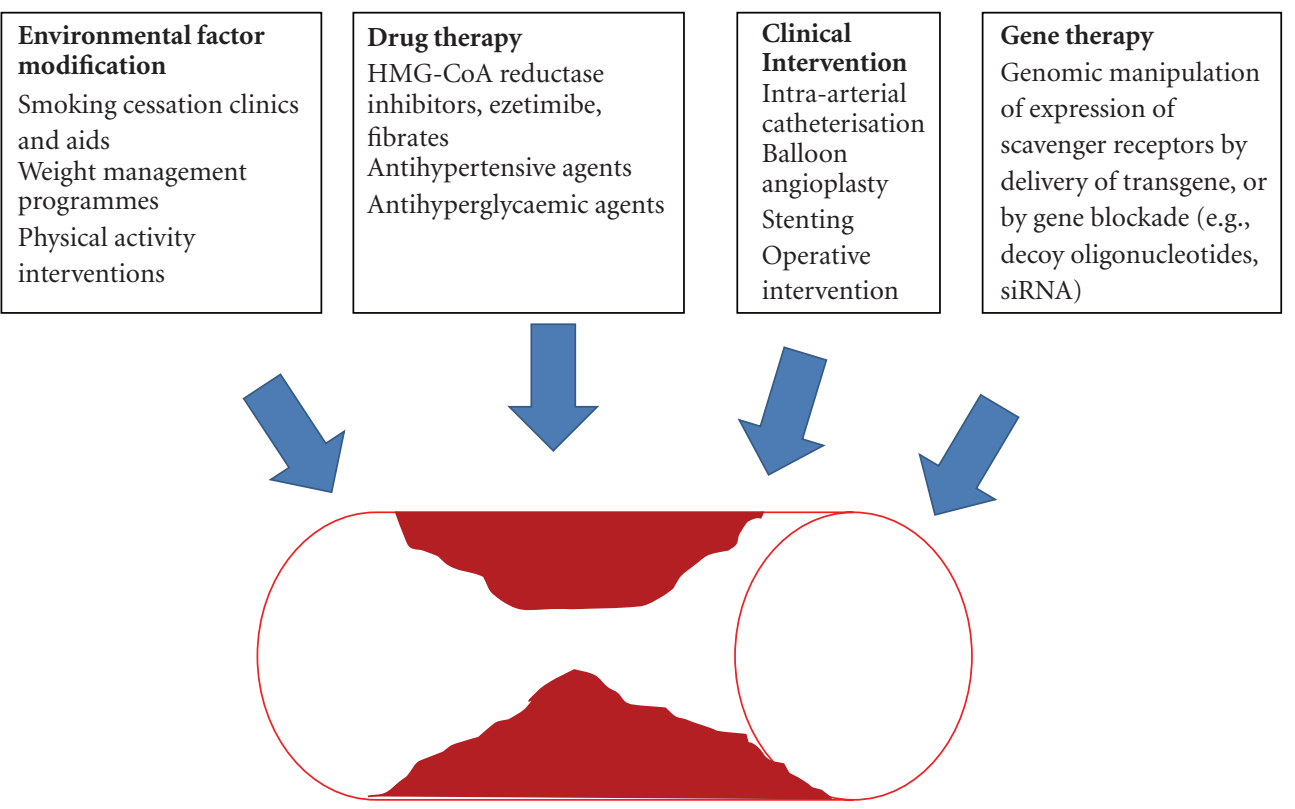

FIGURE 2: Treatment of atherosclerosis. A schematic to display the potential synergistic role of gene therapy in the treatment of atherosclerosis.

7.4. CD36 Gene Therapy. CD36 is another Class B scavenger receptor that can mediate oxidized LDL binding and internalization [284]. Liver overexpression of CD36 using a first-generation adenoviral vector significantly increased cellular fatty acid uptake including hepatic fatty acid, plasma, and hepatic triglycerides [273]. Constitutive expression of murine SR-BI or the murine CD36 using a first-generation adenoviral vector in cultured cells in vitro showed that
SR-BI-mediated uptake of cholesterol esters was higher than CD36 [271]. Hepatic SR-BI overexpression significantly reduced HDL levels whereas CD36 overexpression had little effect [271]. However, in another study using the same in vitro model, CD36-mediated OxLDL internalization resulted in significantly higher lipid particle degradation, compared to SR-BI [272]. These findings suggest significant differences between the two proteins within the same class and that 


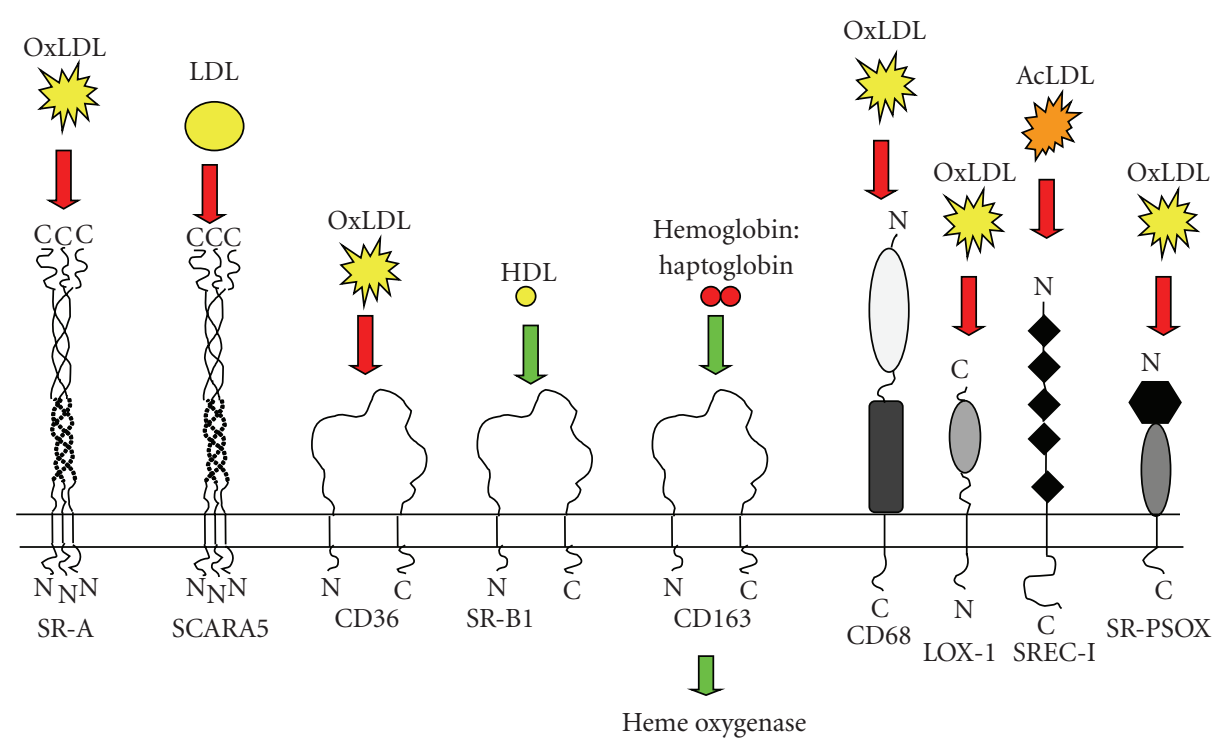

FIGURE 3: Major scavenger receptors and their effects on atherosclerosis. A schematic showing the role of major scavenger receptors in atherosclerosis. Red arrows indicate proatherogenic effects; green arrows indicate antiatherogenic or protective effects. SR-A (scavenger receptor class A) mediates uptake of OxLDL (oxidised low density lipoprotein) in macrophages; SCARA5 (scavenger receptor A5) downregulation results in reduction of aortic LDL (low density lipoprotein) deposition; CD36 is probably a receptor of OxLDL; SR-B (scavenger receptor B) increases cholesterol efflux; CD163 exerts its protective actions through elevation of IL-10 and heme oxygenase; CD68 is a possible receptor for OxLDL; LOX-1 is a receptor for OxLDL; SREC-1 (scavenger receptors expressed by endothelial cells) is a receptor for AcLDL (acetylated low density lipoprotein); SR-PSOX (scavenger receptor that binds to phosphatidylserine and oxidized lipoprotein) binds to OxLDL (figure adapted from [1]).

CD36 overexpression may be more beneficial by promoting the clearance of modified lipid particles.

7.5. SR-PSOX Gene Therapy. The scavenger receptor that binds to phosphatidylserine and oxidized lipoprotein (SRPSOX) is highly expressed within atherosclerotic lesions [111], and elevated expression in macrophages stimulates OxLDL uptake [285]. Reduction of human SR-PSOX levels in immortalized monocytes by RNAi using a lentiviral vector decreased lipid accumulation and foam cell development [120]. However, in double knockout mice lacking both LDL$\mathrm{R}$ and SR-PSOX, there was accelerated atherosclerosis with increased macrophage recruitment to the aortic arch [121]. The potential role of SR-PSOX in the innate immune system to mediate pathogen clearance $[125,286]$ suggests that more studies may be needed to ascertain potential benefits of the SR-PSOX manipulation in vivo.

\section{Conclusions}

Treatment of atherosclerosis using pharmacological agents has only been partially successful, and therefore newer therapies, either stand-alone ones or in combination with the pharmacological agents, are desirable (Figure 2). Gene therapy has been successful in human and animal models with more than 1500 clinical trials worldwide (http://www.wiley.co.uk/genetherapy/clinical/). Viral vectors appear better than nonviral vectors to deliver transgenes to target cells and tissues. Despite the setbacks to viral gene therapy due to insertional mutagenesis caused by the viral vectors or anti-viral host immune responses, better vectors with significant safety biosafety improvements have been developed Self-inactivating lentiviral vectors [245] are safer, and modifications of the viral long terminal repeats further reduce the potential of insertional mutagenesis by retroand lentiviral vectors [287]. Even though viral integrations have been observed near transcription start sites and genes, foamy viruses have reduced preferential integration into host genes [288] in comparison to other viral systems [170, 179], and thus this class of viruses may be significantly safer than retro- or lentiviruses when used as vectors. Most of the adenoviral vectors currently being used are based on Ad5 serotype; however, since neutralizing host antibodies to the Ad5 serotype exceeds that to the Ad36 serotype in the human population [289], Ad36-derived vectors may be better for human clinical trials. Intrahepatic injection of adenoviral vectors also help in reducing the immune response and increasing transgene expression [290]. The problems arising from the preexisting host immune responses against Ad5 serotype can also be circumnavigated using vectors based on a canine adenovirus [224]. Viral vectors can also be made to specifically target the desired cell type [291-294], and this strategy should help in improving the overall efficacy of the therapy.

Even though the first successful clinical gene therapy trial took place almost twenty years ago, work on its utility for modulating scavenger receptor function is still in its infancy (summarized in Table 3). Hepatic overexpression of scavenger receptors using viral vectors resulted in the inhibition of atherosclerosis initiation and progression 
$[263,265,266]$ even though therapy efficacy was hampered by lack of stable long-term gene expression. Better results were obtained when a different viral vector was used [267]. A study of the long-term effect of the transgene expression in vivo using the other available viral vector types would be very desirable to ascertain the potential of using viral gene therapy using scavenger receptors. The splice variant isoforms of some scavenger receptors can confer protection against myocardial infarction [88], and it might be interesting to examine expression of these molecules in an in vivo model. The long-term effects of the expression of soluble scavenger receptors on atherosclerosis would be interesting [265-267]. Since scavenger receptor knockout models can be antiatherogenic [120], suppression of gene expression appears to be a promising strategy although effects on the host immune responses have yet to be fully understood. A dual approach where genetic manipulation of a candidate scavenger receptor is supplemented by the action of another transgene [270] combined with longer duration of transgene expression might increase therapeutic benefits in disease models. Adeno-associated viral vectors may not be very useful in the simultaneous expression of a number of transgenes from a single vector due to the limitations in their packaging capacity, but multiple transgenes can be expressed in the model system with large vectors such as HC-AdVs. Transgene expression from viral vectors such as HC-Ad and lentiviruses is relatively stable and long-lived but these vectors have been used sparingly for such studies with scavenger receptors. With the advent of gene therapy vectors with higher biosafety such as SIN-LV vectors and HC-AdV vectors, development of less immunogenic viral vectors based on nonhuman viruses [224], and suppression of transgene-specific immune responses [295] gene therapy with scavenger receptors along with other therapies might be useful in providing sustained long-term amelioration of the clinical manifestations of atherosclerosis.

\section{Acknowledgment}

The work in the authors' laboratories is supported by the British Heart Foundation (Sreenivasan Ponnambalam, Stephen B. Wheatcroft, and John H. Walker) and Heart Research UK (Sreenivasan Ponnambalam).

\section{References}

[1] J. E. Murphy, P. R. Tedbury, S. Homer-Vanniasinkam, J. H. Walker, and S. Ponnambalam, "Biochemistry and cell biology of mammalian scavenger receptors," Atherosclerosis, vol. 182, no. 1, pp. 1-15, 2005.

[2] J. L. Goldstein, Y. K. Ho, S. K. Basu, and M. S. Brown, "Binding site on macrophages that mediates uptake and degradation of acetylated low density lipoprotein, producing massive cholesterol deposition," Proceedings of the National Academy of Sciences of the United States of America, vol. 76, no. 1, pp. 333-337, 1979.

[3] M. Krieger, "The other side of scavenger receptors: pattern recognition for host defense," Current Opinion in Lipidology, vol. 8, no. 5, pp. 275-280, 1997.
[4] A. Plüddemann, S. Mukhopadhyay, and S. Gordon, "The interaction of macrophage receptors with bacterial ligands," Expert Reviews in Molecular Medicine, vol. 8, no. 28, pp. 1-25, 2006.

[5] A. Plüddemann, C. Neyen, and S. Gordon, "Macrophage scavenger receptors and host-derived ligands," Methods, vol. 43, no. 3, pp. 207-217, 2007.

[6] P. J. Gough, D. R. Greaves, and S. Gordon, "A naturally occurring isoform of the human macrophage scavenger receptor (SR-A) gene generated by alternative splicing blocks modified LDL uptake," Journal of Lipid Research, vol. 39, no. 3, pp. 531-543, 1998.

[7] Y. Jiang, P. Oliver, K. E. Davies, and N. Platt, "Identification and characterization of murine SCARA5, a novel class A scavenger receptor that is expressed by populations of epithelial cells," The Journal of Biological Chemistry, vol. 281, no. 17, pp. 11834-11845, 2006.

[8] M. Freeman, J. Ashkenas, D. J. G. Rees et al., "An ancient, highly conserved family of cysteine-rich protein domains revealed by cloning type I and type II murine macrophage scavenger receptors," Proceedings of the National Academy of Sciences of the United States of America, vol. 87, no. 22, pp. 8810-8814, 1990.

[9] O. Elomaa, M. Kangas, C. Sahlberg et al., "Cloning of a novel bacteria-binding receptor structurally related to scavenger receptors and expressed in a subset of macrophages," Cell, vol. 80, no. 4, pp. 603-609, 1995.

[10] K. Nakamura, H. Funakoshi, K. Miyamoto, F. Tokunaga, and T. Nakamura, "Molecular cloning and functional characterization of a human scavenger receptor with C-type lectin (SRCL), a novel member of a scavenger receptor family," Biochemical and Biophysical Research Communications, vol. 280, no. 4, pp. 1028-1035, 2001.

[11] M. Emi, H. Asaoka, A. Matsumoto et al., "Structure, organization, and chromosomal mapping of the human macrophage scavenger receptor gene," The Journal of Biological Chemistry, vol. 268, no. 3, pp. 2120-2125, 1993.

[12] M. Mietus-Snyder, M. S. Gowri, and R. E. Pitas, "Class A scavenger receptor up-regulation in smooth muscle cells by oxidized low density lipoprotein. Enhancement by calcium flux and concurrent cyclooxygenase-2 up-regulation," The Journal of Biological Chemistry, vol. 275, no. 23, pp. 1766117670, 2000.

[13] V. Terpstra, E. S. van Amersfoort, A. G. van Velzen, J. Kuiper, and T. J. C. van Berkel, "Hepatic and extrahepatic scavenger receptors function in relation to disease," Arteriosclerosis, Thrombosis, and Vascular Biology, vol. 20, no. 8, pp. 1860$1872,2000$.

[14] W. J. S. de Villiers, I. P. Fraser, D. A. Hughes, A. G. Doyle, and S. Gordon, "Macrophage-colony-stimulating factor selectively enhances macrophage scavenger receptor expression and function," Journal of Experimental Medicine, vol. 180, no. 2, pp. 705-709, 1994.

[15] D. P. Via, L. Pons, D. K. Dennison, A. E. Fanslow, and F. Bernini, "Induction of acetyl-LDL receptor activity by phorbol ester in human monocyte cell line THP-1," Journal of Lipid Research, vol. 30, no. 10, pp. 1515-1524, 1989.

[16] V. V. Kunjathoor, M. Febbraio, E. A. Podrez et al., "Scavenger receptors class A-I/II and $\mathrm{CD} 36$ are the principal receptors responsible for the uptake of modified low density lipoprotein leading to lipid loading in macrophages," The Journal of Biological Chemistry, vol. 277, no. 51, pp. 49982-49988, 2002. 
[17] N. Kamada, T. Kodama, and H. Suzuki, "Macrophage scavenger receptor (SR-A I/II) deficiency reduced diet-induced atherosclerosis in C57BL/6J mice," Journal of Atherosclerosis and Thrombosis, vol. 8, no. 1, pp. 1-6, 2001.

[18] H. Suzuki, Y. Kurihara, M. Takeya et al., "A role for macrophage scavenger receptors in atherosclerosis and susceptibility to infection," Nature, vol. 386, no. 6622, pp. 292296, 1997.

[19] M. S. Arredouani, Z. Yang, A. Imrich, Y. Ning, G. Qin, and L. Kobzik, "The macrophage scavenger receptor SR-AI/II and lung defense against pneumococci and particles," American Journal of Respiratory Cell and Molecular Biology, vol. 35, no. 4, pp. 474-478, 2006.

[20] M. Kangas, A. Brännström, O. Elomaa et al., "Structure and chromosomal localization of the human and murine genes for the macrophage MARCO receptor," Genomics, vol. 58, no. 1, pp. 82-89, 1999.

[21] F. Granucci, F. Petralia, M. Urbano et al., "The scavenger receptor MARCO mediates cytoskeleton rearrangements in dendritic cells and microglia," Blood, vol. 102, no. 8, pp. 2940-2947, 2003.

[22] A. Grolleau, D. E. Misek, R. Kuick, S. Hanash, and J. J. Mulé, "Inducible expression of macrophage receptor marco by dendritic cells following phagocytic uptake of dead cells uncovered by oligonucleotide arrays," The Journal of Immunology, vol. 171, no. 6, pp. 2879-2888, 2003.

[23] G. Kraal, L. J. W. van der Laan, O. Elomaa, and K. Tryggvason, "The macrophage receptor MARCO," Microbes and Infection, vol. 2, no. 3, pp. 313-316, 2000.

[24] M. Arredouani, Z. Yang, Y. Y. Ning et al., "The scavenger receptor MARCO is required for lung defense against pneumococcal pneumonia and inhaled particles," Journal of Experimental Medicine, vol. 200, no. 2, pp. 267-272, 2004.

[25] M. S. Arredouani, A. Palecanda, H. Koziel et al., "MARCO is the major binding receptor for unopsonized particles and bacteria on human alveolar macrophages," The Journal of Immunology, vol. 175, no. 9, pp. 6058-6064, 2005.

[26] K. Ohtani, Y. Suzuki, S. Eda et al., "The Membranetype Collectin CL-P1 Is a Scavenger Receptor on Vascular Endothelial Cells," The Journal of Biological Chemistry, vol. 276, no. 47, pp. 44222-44228, 2001.

[27] S. J. Jang, K. Ohtani, A. Fukuoh et al., "Scavenger receptor collectin placenta 1 (CL-P1) predominantly mediates zymosan phagocytosis by human vascular endothelial cells," The Journal of Biological Chemistry, vol. 284, no. 6, pp. 39563965, 2009.

[28] S. Auclair, D. Milenkovic, C. Besson et al., "Catechin reduces atherosclerotic lesion development in apo E-deficient mice: a transcriptomic study," Atherosclerosis, vol. 204, no. 2, pp. e21-e27, 2009.

[29] A. L. Armesilla and M. A. Vega, "Structural organization of the gene for human CD36 glycoprotein," The Journal of Biological Chemistry, vol. 269, no. 29, pp. 18985-18991, 1994.

[30] K. Matsumoto, K. Hirano, S. Nozaki, et al., "Expression of macrophage (Mphi) scavenger receptor, CD36, in cultured human aortic smooth muscle cells in association with expression of peroxisome proliferator activated receptorgamma, which regulates gain of Mphi-like phenotype in vitro, and its implication in atherogenesis," Arteriosclerosis, Thrombosis, and Vascular Biology, vol. 20, pp. 1027-1032, 2000.

[31] D. Calvo, J. Dopazo, and M. A. Vega, "The CD36, CLA1 (CD36L1), and LIMPII (CD36L2) gene family: cellular distribution, chromosomal location, and genetic evolution," Genomics, vol. 25, no. 1, pp. 100-106, 1995.

[32] K. Tsukamoto, M. Kinoshita, K. Kojima et al., "Synergically increased expression of CD36, CLA-1 and CD68, but not of SR-A and LOX-1, with the progression to foam cells from macrophages," Journal of Atherosclerosis and Thrombosis, vol. 9, no. 1, pp. 57-64, 2002.

[33] M. Febbraio, E. A. Podrez, J. D. Smith et al., "Targeted disruption of the class $\mathrm{B}$, scavenger receptor $\mathrm{CD} 36$ protects against atherosclerotic lesion development in mice," The Journal of Clinical Investigation, vol. 105, no. 8, pp. 10491056,2000

[34] J. J. Manning-Tobin, K. J. Moore, T. A. Seimon et al., "Loss of SR-A and CD36 activity reduces atherosclerotic lesion complexity without abrogating foam cell formation in hyperlipidemic mice," Arteriosclerosis, Thrombosis, and Vascular Biology, vol. 29, no. 1, pp. 19-26, 2009.

[35] T. K. Means, E. Mylonakis, E. Tampakakis et al., "Evolutionarily conserved recognition and innate immunity to fungal pathogens by the scavenger receptors SCARF1 and CD36," Journal of Experimental Medicine, vol. 206, no. 3, pp. 637653, 2009.

[36] A. Handberg, M. Norberg, H. Stenlund, G. Hallmans, J. Attermann, and J. W. Eriksson, "Soluble CD36 (sCD36) clusters with markers of insulin resistance, and high sCD36 is associated with increased type 2 diabetes risk," The Journal of Clinical Endocrinology and Metabolism, vol. 95, no. 4, pp. 1939-1946, 2010.

[37] A. Handberg, M. Skjelland, A. E. Michelsen et al., "Soluble CD36 in plasma is increased in patients with symptomatic atherosclerotic carotid plaques and is related to plaque instability," Stroke, vol. 39, no. 11, pp. 3092-3095, 2008.

[38] K. Hoebe, P. Georgel, S. Rutschmann et al., "CD36 is a sensor of diacylglycerides," Nature, vol. 433, no. 7025, pp. 523-527, 2005.

[39] L. M. Stuart, J. Deng, J. M. Silver et al., "Response to Staphylococcus aureus requires CD36-mediated phagocytosis triggered by the COOH-terminal cytoplasmic domain," Journal of Cell Biology, vol. 170, no. 3, pp. 477-485, 2005.

[40] T. J. Aitman, L. D. Cooper, P. J. Norsworthy et al., "Malaria susceptibility and CD36 mutation," Nature, vol. 405, no. 6790, pp. 1015-1016, 2000.

[41] G. Cao, C. K. Garcia, K. L. Wyne, R. A. Schultz, K. L. Parker, and H. H. Hobbs, "Structure and localization of the human gene encoding SR-BI/CLA-1. Evidence for transcriptional control by steroidogenic factor 1," The Journal of Biological Chemistry, vol. 272, no. 52, pp. 33068-33076, 1997.

[42] N. R. Webb, W. J. S. de Villiers, P. M. Connell, F. C. de Beer, and D. R. van der Westhuyzen, "Alternative forms of the scavenger receptor BI (SR-BI)," Journal of Lipid Research, vol. 38, no. 7, pp. 1490-1495, 1997.

[43] D. L. Silver, "SR-BI and protein-protein interactions in hepatic high density lipoprotein metabolism," Reviews in Endocrine and Metabolic Disorders, vol. 5, no. 4, pp. 327-333, 2004.

[44] G. Chinetti, F. G. Gbaguidi, S. Griglio et al., "CLA-1/SR$\mathrm{BI}$ is expressed in atherosclerotic lesion macrophages and regulated by activators of peroxisome proliferator-activated receptors," Circulation, vol. 101, no. 20, pp. 2411-2417, 2000.

[45] C. Langer, B. Gansz, C. Goepfert et al., "Testosterone up-regulates scavenger receptor bi and stimulates cholesterol efflux from macrophages," Biochemical and Biophysical Research Communications, vol. 296, no. 5, pp. 1051-1057, 2002. 
[46] D. K. Spady, D. M. Kearney, and H. H. Hobbs, "Polyunsaturated fatty acids up-regulate hepatic scavenger receptor B1 (SR-BI) expression and HDL cholesteryl ester uptake in the hamster," Journal of Lipid Research, vol. 40, no. 8, pp. 1384 1394, 1999.

[47] Y. Bao, Y. Yang, L. Wang et al., "Identification of trichostatin $A$ as a novel transcriptional up-regulator of scavenger receptor BI both in HepG2 and RAW 264.7 cells," Atherosclerosis, vol. 204, no. 1, pp. 127-135, 2009.

[48] W. Khovidhunkit, A. H. Moser, J. K. Shigenaga, C. Grunfeld, and K. R. Feingold, "Regulation of scavenger receptor class B type I in hamster liver and hep3B cells by endotoxin and cytokines," Journal of Lipid Research, vol. 42, no. 10, pp. 16361644, 2001.

[49] J. Han, A. C. Nicholson, X. Zhou, J. Feng, A. M. Gotto Jr., and D. P. Hajjar, "Oxidized low density lipoprotein decreases macrophage expression of scavenger receptor BI," The Journal of Biological Chemistry, vol. 276, no. 19, pp. 16567-16572, 2001.

[50] M. T. Catanese, H. Ansuini, R. Graziani et al., "Role of scavenger receptor class B type I in hepatitis $\mathrm{C}$ virus entry: kinetics and molecular determinants," Journal of Virology, vol. 84, no. 1, pp. 34-43, 2010.

[51] C. D. Rodrigues, M. Hannus, M. Prudêncio et al., "Host Scavenger Receptor SR-BI Plays a Dual Role in the Establishment of Malaria Parasite Liver Infection," Cell Host and Microbe, vol. 4, no. 3, pp. 271-282, 2008.

[52] G. Schäfer, R. Guler, G. Murray, F. Brombacher, and G. D. Brown, "The role of scavenger receptor B1 in infection with Mycobacterium tuberculosis in a murine model," PloS one, vol. 4, no. 12, Article ID e8448, 2009.

[53] D. J. Rader, "Molecular regulation of HDL metabolism and function: implications for novel therapies," The Journal of Clinical Investigation, vol. 116, no. 12, pp. 3090-3100, 2006.

[54] K. F. Kozarsky, M. H. Donahee, A. Rigotti, S. N. Iqbal, E. R. Edelman, and M. Krieger, "Overexpression of the HDL receptor SR-BI alters plasma HDL and bile cholesterol levels," Nature, vol. 387, no. 6631, pp. 414-417, 1997.

[55] K. F. Kozarsky, M. H. Donahee, J. M. Glick, M. Krieger, and D. J. Rader, "Gene transfer and hepatic overexpression of the HDL receptor SR-BI reduces atherosclerosis in the cholesterol-fed LDL receptor-deficient mouse," Arteriosclerosis, Thrombosis, and Vascular Biology, vol. 20, no. 3, pp. 721$727,2000$.

[56] T. Arai, N. Wang, M. Bezouevski, C. Welch, and A. R. Tall, "Decreased atherosclerosis in heterozygous low density lipoprotein receptor-deficient mice expressing the scavenger receptor BI transgene," The Journal of Biological Chemistry, vol. 274, no. 4, pp. 2366-2371, 1999.

[57] S. K. A. Law, K. J. Micklem, J. M. Shaw et al., "A new macrophage differentiation antigen which is a member of the scavenger receptor superfamily," European The Journal of Immunology, vol. 23, no. 9, pp. 2320-2325, 1993.

[58] M. Ritter, C. Buechler, T. Langmann, and G. Schmitz, "Genomic organization and chromosomal localization of the human CD163 (M130) gene: a member of the scavenger receptor cysteine-rich superfamily," Biochemical and Biophysical Research Communications, vol. 260, no. 2, pp. 466-474, 1999.

[59] A. Droste, C. Sorg, and P. Högger, "Shedding of CD163, a novel regulatory mechanism for a member of the scavenger receptor cysteine-rich family," Biochemical and Biophysical Research Communications, vol. 256, no. 1, pp. 110-113, 1999.
[60] P. Philippidis, J. C. Mason, B. J. Evans et al., "Hemoglobin scavenger receptor CD163 mediates interleukin-10 release and heme oxygenase-1 synthesis: aantiinflammatory monocyte-macrophage responses in vitro, in resolving skin blisters in vivo, and after cardiopulmonary bypass surgery," Circulation Research, vol. 94, no. 1, pp. 119-126, 2004.

[61] S. K. Moestrup and H. J. Moller, "CD163: a regulated hemoglobin scavenger receptor with a role in the antiinflammatory response," Annals of Medicine, vol. 36, no. 5, pp. 347-354, 2004.

[62] H. Van Gorp, P. L. Delputte, and H. J. Nauwynck, "Scavenger receptor CD163, a Jack-of-all-trades and potential target for cell-directed therapy," Molecular Immunology, vol. 47, no. 78, pp. 1650-1660, 2010.

[63] C. A. Gleissner, I. Shaked, C. Erbel, D. Böckler, H. A. Katus, and K. Ley, "CXCL4 downregulates the atheroprotective hemoglobin receptor CD163 in human macrophages," Circulation Research, vol. 106, no. 1, pp. 203-211, 2010.

[64] H. J. Møller, N. A. Peterslund, J. H. Graversen, and S. K. Moestrup, "Identification of the hemoglobin scavenger receptor/CD163 as a natural soluble protein in plasma," Blood, vol. 99, no. 1, pp. 378-380, 2002.

[65] H. J. Møller, M. de Fost, H. Aerts, C. Hollak, and S. K. Moestrup, "Plasma level of the macrophage-derived soluble CD163 is increased and positively correlates with severity in Gaucher's disease," European Journal of Haematology, vol. 72, no. 2, pp. 135-139, 2004.

[66] A. Pearson, A. Lux, and M. Krieger, "Expression cloning of dSR-CI, a class C macrophage-specific scavenger receptor from Drosophila melanogaster," Proceedings of the National Academy of Sciences of the United States of America, vol. 92, no. 9, pp. 4056-4060, 1995.

[67] M. Rämet, A. Pearson, P. Manfruelli et al., "Drosophila scavenger receptor $\mathrm{CI}$ is a pattern recognition receptor for bacteria," Immunity, vol. 15, no. 6, pp. 1027-1038, 2001.

[68] A. Miyashita, N. Shimizu, N. Endo et al., "Five different genes, Eif4a1, Cd68, Supl15h, Sox15 and Fxr2h, are clustered in a $40 \mathrm{~kb}$ region of mouse chromosome 11," Gene, vol. 237, no. 1, pp. 53-60, 1999.

[69] Z. Jiang, D. M. Shih, Y.-R. Xia et al., "Structure, organization, and chromosomal mapping of the gene encoding macrosialin, a macrophage-restricted protein," Genomics, vol. 50, no. 2, pp. 199-205, 1998.

[70] A. C. Li, F. R. B. Guidez, J. G. Collier, and C. K. Glass, “The macrosialin promoter directs high levels of transcriptional activity in macrophages dependent on combinatorial interactions between PU.1 and c- Jun," The Journal of Biological Chemistry, vol. 273, no. 9, pp. 5389-5399, 1998.

[71] H. Yoshida, O. Quehenberger, N. Kondratenko, S. Green, and D. Steinberg, "Minimally oxidized low-density lipoprotein increases expression of scavenger receptor a, CD36, and macrosialin in resident mouse peritoneal macrophages," Arteriosclerosis, Thrombosis, and Vascular Biology, vol. 18, no. 5, pp. 794-802, 1998.

[72] C. L. Holness and D. L. Simmons, "Molecular cloning of CD68, a human macrophage marker related to lysosomal glycoproteins," Blood, vol. 81, no. 6, pp. 1607-1613, 1993.

[73] W. J. S. de Villiers, J. D. Smith, M. Miyata, H. M. Dansky, E. Darley, and S. Gordon, "Macrophage phenotype in mice deficient in both macrophage-colony- stimulating factor (Op) and apolipoprotein E," Arteriosclerosis, Thrombosis, and Vascular Biology, vol. 18, no. 4, pp. 631-640, 1998. 
[74] M. P. Ramprasad, W. Fischer, J. L. Witztum, G. R. Sambrano, O. Quehenberger, and D. Steinberg, "The 94- to 97$\mathrm{kDa}$ mouse macrophage membrane protein that recognizes oxidized low density lipoprotein and phosphatidylserine-rich liposomes is identical to macrosialin, the mouse homologue of human CD68," Proceedings of the National Academy of Sciences of the United States of America, vol. 92, no. 21, pp. 9580-9584, 1995.

[75] M. P. Ramprasad, V. Terpstra, N. Kondratenko, O. Quehenberger, and D. Steinberg, "Cell surface expression of mouse macrosialin and human CD68 and their role as macrophage receptors for oxidized low density lipoprotein," Proceedings of the National Academy of Sciences of the United States of America, vol. 93, no. 25, pp. 14833-14838, 1996.

[76] A. G. Van Velzen, R. P. Da Silva, S. Gordon, and T. J. C. Van Berkel, "Characterization of a receptor for oxidized low-density lipoproteins on rat Kupffer cells: similarity to macrosialin," Biochemical Journal, vol. 322, no. 2, pp. 411415, 1997.

[77] M. C. de Beer, Z. Zhao, N. R. Webb, D. R. van der Westhuyzen, and W. J. S. de Villiers, "Lack of a direct role for macrosialin in oxidized LDL metabolism," Journal of Lipid Research, vol. 44, no. 4, pp. 674-685, 2003.

[78] R. Sawada, K. A. Jardine, and M. Fukuda, "The genes of major lysosomal membrane glycoproteins lamp-1 and lamp2. The 5'-flanking sequence of lamp-2 gene and comparison of exon organization in two genes," The Journal of Biological Chemistry, vol. 268, no. 17, p. 13010, 1993.

[79] B. de Saint-Vis, J. Vincent, S. Vandenabeele et al., "A novel lysosome-associated membrane glycoprotein, DC-LAMP, induced upon DC maturation, is transiently expressed in MHC class II compartment," Immunity, vol. 9, no. 3, pp. 325336, 1998.

[80] S. Yamanaka, X.-Y. Zhang, K. Miura, S. Kim, and H. Iwao, "The human gene encoding the lectin-type oxidized LDL receptor (OLR1) is a novel member of the natural killer gene complex with a unique expression profile," Genomics, vol. 54, no. 2, pp. 191-199, 1998.

[81] T. Sawamura, N. Kume, T. Aoyama et al., "An endothelial receptor for oxidized low-density lipoprotein," Nature, vol. 386, no. 6620, pp. 73-77, 1997.

[82] M. Chen, T. Masaki, and T. Sawamura, "LOX-1, the receptor for oxidized low-density lipoprotein identified from endothelial cells: implications in endothelial dysfunction and atherosclerosis," Pharmacology and Therapeutics, vol. 95, no. 1, pp. 89-100, 2002.

[83] N. Kume, H. Moriwaki, H. Kataoka et al., "Inducible expression of LOX-1, a novel receptor for oxidized LDL, in macrophages and vascular smooth muscle cells," Annals of the New York Academy of Sciences, vol. 902, pp. 323-327, 2000.

[84] T. Murase, N. Kume, R. Korenaga et al., "Fluid shear stress transcriptionally induces lectin-like oxidized LDL receptor1 in vascular endothelial cells," Circulation Research, vol. 83, no. 3, pp. 328-333, 1998.

[85] H. Morawietz, U. Rueckschloss, B. Niemann et al., "Angiotensin II induces LOX-1, the human endothelial receptor for oxidized low-density lipoprotein," Circulation, vol. 100, no. 9, pp. 899-902, 1999.

[86] H. Morawietz, N. Duerrschmidt, B. Niemann, J. Galle, T. Sawamura, and J. Holtz, "Induction of the OxLDL receptor LOX-1 by endothelin-1 in human endothelial cells," Biochemical and Biophysical Research Communications, vol. 284, no. 4, pp. 961-965, 2001.
[87] D. Y. Li, Y. C. Zhang, M. I. Philips, T. Sawamura, and J. L. Mehta, "Upregulation of endothelial receptor for oxidized low-density lipoprotein (LOX-1) in cultured human coronary artery endothelial cells by angiotensin II type 1 receptor activation," Circulation Research, vol. 84, no. 9, pp. 1043-1049, 1999.

[88] R. Mango, S. Biocca, F. Del Vecchio et al., "In vivo and in vitro studies support that a new splicing isoform of OLR1 gene is protective against acute myocardial infarction," Circulation Research, vol. 97, no. 2, pp. 152-158, 2005.

[89] S. Biocca, I. Filesi, R. Mango et al., "The splice variant LOXIN inhibits LOX-1 receptor function through heterooligomerization," Journal of Molecular and Cellular Cardiology, vol. 44, no. 3, pp. 561-570, 2008.

[90] M. Tatsuguchi, M. Furutani, J.-I. Hinagata et al., "Oxidized LDL receptor gene (OLR1) is associated with the risk of myocardial infarction," Biochemical and Biophysical Research Communications, vol. 303, no. 1, pp. 247-250, 2003.

[91] S. Biocca, M. Falconi, I. Filesi et al., "Functional analysis and molecular dynamics simulation of LOX-1 K167N polymorphism reveal alteration of receptor activity," PLOS ONE, vol. 4, no. 2, Article ID e4648, 2009.

[92] Ö. Kurnaz, H. Y. Aydoğan, C. S. Isbir, A. Tekeli, and T. Isbir, "Is LOX-1 K167N polymorphism protective for coronary artery disease?" In Vivo, vol. 23, no. 6, pp. 969-973, 2009.

[93] J. W. Knowles, T. L. Assimes, E. Boerwinkle et al., "Failure to replicate an association of SNPs in the oxidized LDL receptor gene (OLR1) with CAD," BMC Medical Genetics, vol. 9, article 23, 2008.

[94] T. E. Brinkley, N. Kume, H. Mitsuoka, D. A. Phares, and J. M. Hagberg, "Elevated soluble lectin-like oxidized LDL receptor-1 (sLOX-1) levels in obese postmenopausal women," Obesity, vol. 16, no. 6, pp. 1454-1456, 2008.

[95] K. C. B. Tan, S. W. M. Shiu, Y. Wong, L. Leng, and R. Bucala, "Soluble lectin-like oxidized low density lipoprotein receptor-1 in type 2 diabetes mellitus," Journal of Lipid Research, vol. 49, no. 7, pp. 1438-1444, 2008.

[96] T. Murase, N. Kume, H. Kataoka et al., "Identification of soluble forms of lectin-like oxidized LDL receptor-1," Arteriosclerosis, Thrombosis, and Vascular Biology, vol. 20, no. 3, pp. 715-720, 2000.

[97] K. Hayashida, N. Kume, T. Murase et al., "Serum soluble lectin-like oxidized low-density lipoprotein receptor-1 levels are elevated in acute coronary syndrome a novel marker for early diagnosis," Circulation, vol. 112, no. 6, pp. 812-818, 2005.

[98] Y. Delneste, G. Magistrelli, J.-F. Gauchat et al., "Involvement of LOX-1 in dendritic cell-mediated antigen crosspresentation," Immunity, vol. 17, no. 3, pp. 353-362, 2002.

[99] T. Shimaoka, N. Kume, M. Minami et al., "LOX-1 supports adhesion of Gram-positive and Gram-negative bacteria," The Journal of Immunology, vol. 166, no. 8, pp. 5108-5114, 2001.

[100] I. V. Smirnova, M. Kajstura, T. Sawamura, and M. S. Goligorsky, "Asymmetric dimethylarginine upregulates LOX1 in activated macrophages: role in foam cell formation," American Journal of Physiology, vol. 287, no. 2, pp. H782H790, 2004.

[101] J. L. Mehta, N. Sanada, C. P. Hu et al., "Deletion of LOX1 reduces atherogenesis in LDLR knockout mice fed high cholesterol diet," Circulation Research, vol. 100, no. 11, pp. 1634-1642, 2007.

[102] Y. Tamura, J.-I. Osuga, H. Adachi et al., "Scavenger receptor expressed by endothelial cells I (SREC-I) mediates the uptake of acetylated low density lipoproteins by macrophages 
stimulated with lipopolysaccharide," The Journal of Biological Chemistry, vol. 279, no. 30, pp. 30938-30944, 2004.

[103] T. L. Gumienny and M. O. Hengartner, "How the worm removes corpses: the nematode C. elegans as a model system to study engulfment," Cell Death and Differentiation, vol. 8, no. 6 , pp. 564-568, 2001.

[104] H. Adachi, M. Tsujimoto, H. Arai, and K. Inouel, "Expression cloning of a novel scavenger receptor from human endothelial cells," The Journal of Biological Chemistry, vol. 272, no. 50, pp. 31217-31220, 1997.

[105] H. Adachi and M. Tsujimoto, "Characterization of the human gene encoding the scavenger receptor expressed by endothelial cell and its regulation by a novel transcription factor, endothelial zinc finger protein-2," The Journal of Biological Chemistry, vol. 277, no. 27, pp. 24014-24021, 2002.

[106] J. Ishii, H. Adachi, J. Aoki et al., "SREC-II, a new member of the scavenger receptor type F family, trans-interacts with SREC-I through its extracellular domain," The Journal of Biological Chemistry, vol. 277, no. 42, pp. 39696-39702, 2002.

[107] J. Lund, F. Chen, A. Hua et al., "Comparative sequence analysis of $634 \mathrm{~kb}$ of the mouse chromosome 16 region of conserved synteny with the human velocardiofacial syndrome region on chromosome 22q11.2," Genomics, vol. 63, no. 3, pp. 374-383, 2000.

[108] Z. Zhou, E. Hartwieg, and H. R. Horvitz, "CED-1 is a transmembrane receptor that mediates cell corpse engulfment in C. elegans," Cell, vol. 104, no. 1, pp. 43-56, 2001.

[109] D. Chen, H. Xiao, K. Zhang et al., "Retromer is required for apoptotic cell clearance by phagocytic receptor recycling," Science, vol. 327, no. 5970, pp. 1261-1264, 2010.

[110] T. Shimaoka, N. Kume, M. Minami et al., "Molecular cloning of a novel scavenger receptor for oxidized low density lipoprotein, SR-PSOX, on macrophages," The Journal of Biological Chemistry, vol. 275, no. 52, pp. 40663-40666, 2000.

[111] M. Minami, N. Kume, T. Shimaoka et al., "Expression of SR-PSOX, a novel cell-surface scavenger receptor for phosphatidylserine and oxidized LDL in human atherosclerotic lesions," Arteriosclerosis, Thrombosis, and Vascular Biology, vol. 21, no. 11, pp. 1796-1800, 2001.

[112] S. Tabata, N. Kadowaki, T. Kitawaki et al., "Distribution and kinetics of SR-PSOX/CXCL16 and CXCR6 expression on human dendritic cell subsets and CD4+ T cells," Journal of Leukocyte Biology, vol. 77, no. 5, pp. 777-786, 2005.

[113] S. Abel, C. Hundhausen, R. Mentlein et al., "The transmembrane CXC-chemokine ligand 16 is induced by IFN- $\gamma$ and TNF- $\alpha$ and shed by the activity of the disintegrin-like $\mathrm{m}$ etalloproteinase ADAM10," The Journal of Immunology, vol. 172, no. 10, pp. 6362-6372, 2004.

[114] O. Hofnagel, B. Luechtenborg, G. Plenz, H. Robenek, and $\mathrm{N}$. Kume, "Expression of the novel scavenger receptor SRPSOX in cultured aortic smooth muscle cells and umbilical endothelial cells," Arteriosclerosis, Thrombosis, and Vascular Biology, vol. 22, no. 4, pp. 710-711, 2002.

[115] D. Wågsäter, P. S. Olofsson, L. Norgren, B. Stenberg, and A. Sirsjö, "The chemokine and scavenger receptor CXCL16/SRPSOX is expressed in human vascular smooth muscle cells and is induced by interferon $\gamma$," Biochemical and Biophysical Research Communications, vol. 325, no. 4, pp. 1187-1193, 2004.

[116] T. Shimaoka, T. Nakayama, N. Kume et al., "Cutting edge: SR-PSOX/CXC chemokine ligand 16 mediates bacterial phagocytosis by APCs through its chemokine domain," The Journal of Immunology, vol. 171, no. 4, pp. 1647-1651, 2003.
[117] A. Wilbanks, S. C. Zondlo, K. Murphy et al., "Expression cloning of the STRL33/BONZO/TYMSTR ligand reveals elements of CC, CXC, and CX3C chemokines," The Journal of Immunology, vol. 166, no. 8, pp. 5145-5154, 2001.

[118] A. Schramme, M. S. Abdel-Bakky, P. Gutwein et al., "Characterization of CXCL16 and ADAM10 in the normal and transplanted kidney," Kidney International, vol. 74, no. 3, pp. 328-338, 2008.

[119] P. Shashkin, D. Simpson, V. Mishin, B. Chesnutt, and K. Ley, "Expression of CXCL16 in human T cells," Arteriosclerosis, Thrombosis, and Vascular Biology, vol. 23, no. 1, pp. 148-149, 2003.

[120] L. Zhang, H.-J. Liu, T.-J. Li et al., "Lentiviral vector-mediated siRNA knockdown of SR-PSOX inhibits foam cell formation in vitro," Acta Pharmacologica Sinica, vol. 29, no. 7, pp. 847852, 2008.

[121] A. M. Aslanian and I. F. Charo, "Targeted disruption of the scavenger receptor and chemokine CXCL16 accelerates atherosclerosis," Circulation, vol. 114, no. 6, pp. 583-590, 2006.

[122] M. Lehrke, S. C. Millington, M. Lefterova et al., "CXCL16 is a marker of inflammation, atherosclerosis, and acute coronary syndromes in humans," Journal of the American College of Cardiology, vol. 49, no. 4, pp. 442-449, 2007.

[123] N. Fukumoto, T. Shimaoka, H. Fujimura et al., "Critical roles of CXC chemokine ligand 16/scavenger receptor that binds phosphatidylserine and oxidized lipoprotein in the pathogenesis of both acute and adoptive transfer experimental autoimmune encephalomyelitis," The Journal of Immunology, vol. 173, no. 3, pp. 1620-1627, 2004.

[124] R. Yamauchi, M. Tanaka, N. Kume et al., "Upregulation of SR-PSOX/CXCL16 and recruitment of CD4+ T cells in cardiac valves during inflammatory valvular heart disease," Arteriosclerosis, Thrombosis, and Vascular Biology, vol. 24, no. 2, pp. 282-287, 2004.

[125] T. Shimaoka, T. Nakayama, N. Fukumoto et al., "Cell surfaceanchored SR-PSOX/CXC chemokine ligand 16 mediates firm adhesion of CXC chemokine receptor 6-expressing cells," Journal of Leukocyte Biology, vol. 75, no. 2, pp. 267-274, 2004.

[126] H. Mitsuoka, M. Toyohara, N. Kume et al., "Circulating soluble SR-PSOX/CXCL16 as a biomarker for acute coronary syndrome -comparison with high-sensitivity c-reactive protein," Journal of Atherosclerosis and Thrombosis, vol. 16, no. 5, pp. 586-593, 2009.

[127] M. Salmi, K. Koskinen, T. Henttinen, K. Elima, and S. Jalkanen, "CLEVER-1 mediates lymphocyte transmigration through vascular and lymphatic endothelium," Blood, vol. 104, no. 13, pp. 3849-3857, 2004.

[128] H. Adachi and M. Tsujimoto, "FEEL-1, a novel scavenger receptor with in vitro bacteria-binding and angiogenesismodulating activities," The Journal of Biological Chemistry, vol. 277, no. 37, pp. 34264-34270, 2002.

[129] O. Politz, A. Gratchev, P. A. G. McCourt et al., "Stabilin-1 and -2 constitute a novel family of fasciclin-like hyaluronan receptor homologues," Biochemical Journal, vol. 362, no. 1, pp. 155-164, 2002.

[130] H. Irjala, E.-L. Johansson, M. Merinen et al., "The same endothelial receptor controls lymphocyte traffic both in vascular and lymphatic vessels," European The Journal of Immunology, vol. 33, no. 3, pp. 815-824, 2003.

[131] M. Falkowski, K. Schledzewski, B. Hansen, and S. Goerdt, "Expression of stabilin-2, a novel fasciclin-like hyaluronan receptor protein, in murine sinusoidal endothelia, avascular 
tissues, and at solid/ liquid interfaces," Histochemistry and Cell Biology, vol. 120, no. 5, pp. 361-369, 2003.

[132] S. W. Kuan, K. Proulx, M. S. Rost, and S. Sumanas, "Identification of vasculature-specific genes by microarray analysis of Etsrp/Etv2 overexpressing zebrafish embryos," Developmental Dynamics, vol. 238, no. 7, pp. 1836-1850, 2009.

[133] H. Adachi and M. Tsujimoto, "Adaptor protein sorting nexin 17 interacts with the scavenger receptor FEEL-1/stabilin-1 and modulates its expression on the cell surface," Biochimica et Biophysica Acta-Molecular Cell Research, vol. 1803, no. 5, pp. 553-563, 2010.

[134] M. Becker, A. Cotena, S. Gordon, and N. Platt, "Expression of the class A macrophage scavenger receptor on specific subpopulations of murine dendritic cells limits their endotoxin response," European The Journal of Immunology, vol. 36, no. 4, pp. 950-960, 2006.

[135] J. M. Brown, E. J. Swindle, N. M. Kushnir-Sukhov, A. Holian, and D. D. Metcalfe, "Silica-directed mast cell activation is enhanced by scavenger receptors," American Journal of Respiratory Cell and Molecular Biology, vol. 36, no. 1, pp. 4352, 2007.

[136] D. A. Hughes, I. P. Fraser, and S. Gordon, "Murine macrophage scavenger recepor: in vivo expression and function as receptor for macrophage adhesion in lymphoid and non-lymphoid organs," European The Journal of Immunology, vol. 25, no. 2, pp. 466-473, 1995.

[137] M. Naito, H. Suzuki, T. Mori, A. Matsumoto, T. Kodama, and K. Takahashi, "Coexpression of type I and type II human macrophage scavenger receptors in macrophages of various organs and foam cells in atherosclerotic lesions," American Journal of Pathology, vol. 141, no. 3, pp. 591-599, 1992.

[138] J. Feng, J. Han, S. F. A. Pearce et al., "Induction of CD36 expression by oxidized LDL and IL- 4 by a common signaling pathway dependent on protein kinase C and PPAR- $y$," Journal of Lipid Research, vol. 41, no. 5, pp. 688-698, 2000.

[139] D. Li and J. L. Mehta, "Upregulation of endothelial receptor for oxidized LDL (LOX-1) by oxidized LDL and implications in apoptosis of coronary artery endothelial cells: evidence from use of antisense LOX-1 mRNA and chemical inhibitors," Arteriosclerosis, Thrombosis, and Vascular Biology, vol. 20, no. 4, pp. 1116-1122, 2000.

[140] A. K. Soutar and B. L. Knight, "Structure and regulation of the LDL-receptor and its gene," British Medical Bulletin, vol. 46, no. 4, pp. 891-916, 1990.

[141] X. Shi, S. Niimi, T. Ohtani, and S. Machida, "Characterization of residues and sequences of the carbohydrate recognition domain required for cell surface localization and ligand binding of human lectin-like oxidized LDL receptor," Journal of Cell Science, vol. 114, no. 7, pp. 1273-1282, 2001.

[142] N. S. Kar, M. Z. Ashraf, M. Valiyaveettil, and E. A. Podrez, "Mapping and characterization of the binding site for specific oxidized phospholipids and oxidized low density lipoprotein of scavenger receptor CD36," The Journal of Biological Chemistry, vol. 283, no. 13, pp. 8765-8771, 2008.

[143] E. Reaven, Y. Cortez, S. Leers-Sucheta, A. Nomoto, and S. Azhar, "Dimerization of the scavenger receptor class B type I: formation, function, and localization in diverse cells and tissues," Journal of Lipid Research, vol. 45, no. 3, pp. 513-528, 2004.

[144] T. Kodama, P. Reddy, C. Kishimoto, and M. Krieger, "Purification and characterization of a bovine acetyl low density lipoprotein receptor," Proceedings of the National Academy of Sciences of the United States of America, vol. 85, no. 23, pp. 9238-9242, 1988.
[145] S. Matsunaga, Q. Xie, M. Kumano et al., "Lectin-like oxidized low-density lipoprotein receptor (LOX-1) functions as an oligomer and oligomerization is dependent on receptor density," Experimental Cell Research, vol. 313, no. 6, pp. 1203$1214,2007$.

[146] Y. Chen, X. Wang, J. Ben et al., "The di-leucine motif contributes to class A scavenger receptor-mediated internalization of acetylated lipoproteins," Arteriosclerosis, Thrombosis, and Vascular Biology, vol. 26, no. 6, pp. 1317-1322, 2006.

[147] J. E. Murphy, R. S. Vohra, S. Dunn et al., "Oxidised LDL internalisation by the LOX-1 scavenger receptor is dependent on a novel cytoplasmic motif and is regulated by dynamin-2," Journal of Cell Science, vol. 121, no. 13, pp. 2136-2147, 2008.

[148] Y. Zeng, N. Tao, K.-N. Chung, J. E. Heuser, and D. M. Lublin, "Endocytosis of oxidized low density lipoprotein through scavenger receptor CD36 utilizes a lipid raft pathway that does not require caveolin-1," The Journal of Biological Chemistry, vol. 278, no. 46, pp. 45931-45936, 2003.

[149] S. O. Rahaman, D. J. Lennon, M. Febbraio, E. A. Podrez, S. L. Hazen, and R. Silverstein, "A CD36-dependent signaling cascade is necessary for macrophage foam cell formation," Cell Metabolism, vol. 4, no. 3, pp. 211-221, 2006.

[150] S. S. P. Allender, P. Scarborough, V Peto, et al., European Cardiovascular Disease Statistics, European Heart Network, Brussels, Belgium, 3rd edition, 2008.

[151] C. Baigent, A. Keech, and P. M. Kearney, "Efficacy and safety of cholesterol-lowering treatment: prospective meta-analysis of data from 90,056 participants in 14 randomised trials of statins," The Lancet, vol. 366, pp. 1267-1278, 2005.

[152] C. Comparato, C. Altana, S. Bellosta, R. Baetta, R. Paoletti, and A. Corsini, "Clinically relevant pleiotropic effects of statins: drug properties or effects of profound cholesterol reduction?" Nutrition, Metabolism and Cardiovascular Diseases, vol. 11, no. 5, pp. 328-343, 2001.

[153] M. W. Nirenberg, "Will society be prepared?" Science, vol. 157, no. 3789, p. 633, 1967.

[154] S. Rogers, A. Lowenthal, H. G. Terheggen, and J. P. Columbo, "Induction of arginase activity with the Shope papilloma virus in tissue culture cells from an argininemic patient," Journal of Experimental Medicine, vol. 137, no. 4, pp. 10911096, 1973

[155] N. Wade, "UCLA gene therapy racked by friendly fire," Science, vol. 210, no. 4469, pp. 509-511, 1980.

[156] W. F. Anderson, "Human gene therapy," Science, vol. 256, no. 5058, pp. 808-813, 1992.

[157] W. F. Anderson, "The best of times, the worst of times," Science, vol. 288, no. 5466, pp. 627-629, 2000.

[158] I. M. Verma and M. D. Weitzman, "Gene therapy: twentyfirst century medicine," Annual Review of Biochemistry, vol. 74, pp. 711-738, 2005.

[159] B. D. Brown, G. Sitia, A. Annoni et al., "In vivo administration of lentiviral vectors triggers a type I interferon response that restricts hepatocyte gene transfer and promotes vector clearance," Blood, vol. 109, no. 7, pp. 2797-2805, 2007.

[160] J. Y. Sun, V. Anand-Jawa, S. Chatterjee, and K. K. Wong Jr., "Immune responses to adeno-associated virus and its recombinant vectors," Gene Therapy, vol. 10, no. 11, pp. 964976, 2003.

[161] N. Brunetti-Pierri, D. J. Palmer, A. L. Beaudet, K. D. Carey, M. Finegold, and P. Ng, "Acute toxicity after high-dose systemic injection of helper-dependent adenoviral vectors into nonhuman primates," Human Gene Therapy, vol. 15, no. 1, pp. 35-46, 2004. 
[162] , "Assessment of adenoviral vector safety and toxicity: report of the National Institutes of Health recombinant DNA advisory committee," Human Gene Therapy, vol. 13, no. 1, pp. 3-13, 2002.

[163] S. E. Raper, N. Chirmule, F. S. Lee et al., "Fatal systemic inflammatory response syndrome in a ornithine transcarbamylase deficient patient following adenoviral gene transfer," Molecular Genetics and Metabolism, vol. 80, no. 1-2, pp. 148-158, 2003.

[164] Z. Li, J. Düllmann, B. Schiedlmeier et al., "Murine leukemia induced by retroviral gene marking," Science, vol. 296, no. 5567, p. 497, 2002.

[165] S. Hacein-Bey-Abina, C. von Kalle, M. Schmidt et al., "A serious adverse event after successful gene therapy for $\mathrm{X}$-linked severe combined immunodeficiency," The New England Journal of Medicine, vol. 348, no. 3, pp. 255-256, 2003.

[166] S. Hacein-Bey-Abina, C. Von Kalle, M. Schmidt et al., "LMO2-Associated Clonal T Cell Proliferation in Two Patients after Gene Therapy for SCID-X1," Science, vol. 302, no. 5644, pp. 415-419, 2003.

[167] S. J. Howe, M. R. Mansour, K. Schwarzwaelder et al., "Insertional mutagenesis combined with acquired somatic mutations causes leukemogenesis following gene therapy of SCID-X1 patients," The Journal of Clinical Investigation, vol. 118, no. 9, pp. 3143-3150, 2008.

[168] W. Qasim, H. B. Gaspar, and A. J. Thrasher, "Progress and prospects: gene therapy for inherited immunodeficiencies," Gene Therapy, vol. 16, no. 11, pp. 1285-1291, 2009.

[169] X. Wu, Y. Li, B. Crise, and S. M. Burgess, "Transcription start regions in the human genome are favored targets for MLV integration," Science, vol. 300, no. 5626, pp. 1749-1751, 2003.

[170] R. S. Mitchell, B. F. Beitzel, A. R. W. Schroder et al., "Retroviral DNA integration: ASLV, HIV, and MLV show distinct target site preferences," PLoS Biology, vol. 2, no. 8, article E234, 2004.

[171] U. Modlich, S. Navarro, D. Zychlinski et al., "Insertional transformation of hematopoietic cells by self-inactivating lentiviral and gammaretroviral vectors," Molecular Therapy, vol. 17, no. 11, pp. 1919-1928, 2009.

[172] M. Bokhoven, S. L. Stephen, S. Knight et al., "Insertional gene activation by lentiviral and gammaretroviral vectors," Journal of Virology, vol. 83, no. 1, pp. 283-294, 2009.

[173] A. Beaton, P. Palumbo, and K. I. Berns, "Expression from the adeno-associated virus $\mathrm{p} 5$ and $\mathrm{p} 19$ promoters is negatively regulated in trans by the rep protein," Journal of Virology, vol. 63, no. 10, pp. 4450-4454, 1989.

[174] T. R. Flotte, S. A. Afione, R. Solow et al., "Expression of the cystic fibrosis transmembrane conductance regulator from a novel adeno-associated virus promoter," The Journal of Biological Chemistry, vol. 268, no. 5, pp. 3781-3790, 1993.

[175] L. Hatfield and P. Hearing, "Redundant elements in the adenovirus type 5 inverted terminal repeat promote bidirectional transcription in vitro and are important for virus growth in vivo," Virology, vol. 184, no. 1, pp. 265-276, 1991.

[176] L. Xing and S. K. Tikoo, "Promoter activity of left inverted terminal repeat and downstream sequences of porcine adenovirus type 3," Virus Research, vol. 109, no. 1, pp. 51-58, 2005.

[177] K. Matsumoto, K. Nagata, K. Yamanaka, F. Hanaoka, and M. Ui, "Nuclear factor I represses the reverse-oriented transcription from the adenovirus type 5 DNA terminus," Biochemical and Biophysical Research Communications, vol. 164, no. 3, pp. 1212-1219, 1989.
[178] H. Wang, D. M. Shayakhmetov, T. Leege et al., "A capsidmodified helper-dependent adenovirus vector containing the $\beta$-globin locus control region displays a nonrandom integration pattern and allows stable, erythroid-specific gene expression," Journal of Virology, vol. 79, no. 17, pp. 1099911013, 2005.

[179] S. L. Stephen, V. G. Sivanandam, and S. Kochanek, "Homologous and heterologous recombination between adenovirus vector DNA and chromosomal DNA," Journal of Gene Medicine, vol. 10, no. 11, pp. 1176-1189, 2008.

[180] H. Nakai, E. Montini, S. Fuess, T. A. Storm, M. Grompe, and M. A. Kay, "AAV serotype 2 vectors preferentially integrate into active genes in mice," Nature Genetics, vol. 34, no. 3, pp. 297-302, 2003.

[181] H. Nakai, X. Wu, S. Fuess et al., "Large-scale molecular characterization of adeno-associated virus vector integration in mouse liver," Journal of Virology, vol. 79, no. 6, pp. 36063614, 2005.

[182] D. G. Miller, E. A. Rutledge, and D. W. Russell, "Chromosomal effects of adeno-associated virus vector integration," Nature Genetics, vol. 30, no. 2, pp. 147-148, 2002.

[183] D. M. McCarty, S. M. Young Jr., and R. J. Samulski, "Integration of adeno-associated virus (AAV) and recombinant AAV vectors," Annual Review of Genetics, vol. 38, pp. 819845, 2004.

[184] D. G. Miller, G. D. Trobridge, L. M. Petek, M. A. Jacobs, R. Kaul, and D. W. Russell, "Large-scale analysis of adenoassociated virus vector integration sites in normal human cells," Journal of Virology, vol. 79, no. 17, pp. 11434-11442, 2005.

[185] U. Griesenbach and E. W. F. W. Alton, "Gene transfer to the lung: lessons learned from more than 2 decades of CF gene therapy," Advanced Drug Delivery Reviews, vol. 61, no. 2, pp. 128-139, 2009.

[186] R. Sokolic, C. Kesserwan, and F. Candotti, "Recent advances in gene therapy for severe congenital immunodeficiency diseases," Current Opinion in Hematology, vol. 15, no. 4, pp. 375-380, 2008.

[187] G. Liu, D. Li, M. K. Pasumarthy et al., "Nanoparticles of compacted DNA transfect postmitotic cells," The Journal of Biological Chemistry, vol. 278, no. 35, pp. 32578-32586, 2003.

[188] X.-Q. Ding, A. B. Quiambao, J. B. Fitzgerald, M. J. Cooper, S. M. Conley, and M. I. Naash, "Ocular delivery of compacted DNA-nanoparticles does not elicit toxicity in the mouse retina," PLoS ONE, vol. 4, no. 10, Article ID e7410, 2009.

[189] W. Li and F. C. Szoka Jr., "Lipid-based nanoparticles for nucleic acid delivery," Pharmaceutical Research, vol. 24, no. 3, pp. 438-449, 2007.

[190] V. Kinet, N.-Q.-N. Nguyen, C. Sabatel et al., "Antiangiogenic liposomal gene therapy with $16 \mathrm{~K}$ human prolactin efficiently reduces tumor growth," Cancer Letters, vol. 284, no. 2, pp. 222-228, 2009.

[191] F. Liu, L. M. Shollenberger, C. C. Conwell, X. Yuan, and L. Huang, "Mechanism of naked DNA clearance after intravenous injection," Journal of Gene Medicine, vol. 9, no. 7, pp. 613-619, 2007.

[192] M.-L. Chang, J.-C. Chen, C.-T. Yeh et al., "Gene gun bombardment with DNA-coated gold particles is a potential alternative to hydrodynamics-based transfection for delivering genes into superficial hepatocytes," Human Gene Therapy, vol. 19, no. 4, pp. 391-395, 2008. 
[193] W. G. Marshall Jr., B. A. Boone, J. D. Burgos et al., "Electroporation-mediated delivery of a naked DNA plasmid expressing VEGF to the porcine heart enhances protein expression," Gene Therapy, 2009.

[194] Y. Nakazawa, L. E. Huye, G. Dotti et al., "Optimization of the piggybac transposon system for the sustained genetic modification of human T lymphocytes," Journal of Immunotherapy, vol. 32, no. 8, pp. 826-836, 2009.

[195] H. Parekh-Olmedo, K. Czymmek, and E. B. Kmiec, “Targeted gene repair in mammalian cells using chimeric RNA/DNA oligonucleotides and modified single-stranded vectors," Science, vol. 2001, no. 73, article PL1, 2001.

[196] M. A. Mintzer and E. E. Simanek, "Nonviral vectors for gene delivery," Chemical Reviews, vol. 109, no. 2, pp. 259-302, 2009.

[197] K. Kawabata, Y. Takakura, and M. Hashida, "The fate of plasmid DNA after intravenous injection in mice: involvement of scavenger receptors in its hepatic uptake," Pharmaceutical Research, vol. 12, no. 6, pp. 825-830, 1995.

[198] Y. Takakura, M. Nishikawa, F. Yamashita, and M. Hashida, "Development of gene drug delivery systems based on pharmacokinetic studies," European Journal of Pharmaceutical Sciences, vol. 13, no. 1, pp. 71-76, 2001.

[199] M. Nishikawa, Y. Takakura, and M. Hashida, "Pharmacokinetic considerations regarding non-viral cancer gene therapy," Cancer Science, vol. 99, no. 5, pp. 856-862, 2008.

[200] M. Miyazaki, Y. Obata, K. Abe et al., "Gene transfer using nonviral delivery systems," Peritoneal Dialysis International, vol. 26, no. 6, pp. 633-640, 2006.

[201] F. Jacobs, J. Snoeys, Y. Feng, et al., "Direct comparison of hepatocyte-specific expression cassettes following adenoviral and nonviral hydrodynamic gene transfer," Gene Therapy, vol. 15, pp. 594-603, 2008.

[202] A. D. Judge, V. Sood, J. R. Shaw, D. Fang, K. McClintock, and I. MacLachlan, "Sequence-dependent stimulation of the mammalian innate immune response by synthetic siRNA," Nature Biotechnology, vol. 23, no. 4, pp. 457-462, 2005.

[203] J.-S. Zhang, F. Liu, and L. Huang, "Implications of pharmacokinetic behavior of lipoplex for its inflammatory toxicity," Advanced Drug Delivery Reviews, vol. 57, no. 5, pp. 689-698, 2005.

[204] K. Sellins, L. Fradkin, D. Liggitt, and S. Dow, "Type I interferons potently suppress gene expression following gene delivery using liposome-DNA complexes," Molecular Therapy, vol. 12, no. 3, pp. 451-459, 2005.

[205] X. Gao, K.-S. Kim, and D. Liu, "Nonviral gene delivery: what we know and what is next," AAPS Journal, vol. 9, no. 1, 2007.

[206] K. S. Matthews, R. D. Alvarez, and D. T. Curiel, "Advancements in adenoviral based virotherapy for ovarian cancer," Advanced Drug Delivery Reviews, vol. 61, no. 10, pp. 836-841, 2009.

[207] N. A. Kootstra and I. M. Verma, "Gene therapy with viral vectors," Annual Review of Pharmacology and Toxicology, vol. 43, pp. 413-439, 2003.

[208] R. J. Samulski, A. Strivastava, K. I. Berns, and N. Muzyczka, "Rescue of adeno-associated virus with recombinant plasmids: gene correction within the terminal repeats of AAV," Cell, vol. 33, no. 1, pp. 135-143, 1983.

[209] S. Daya and K. I. Berns, "Gene therapy using adenoassociated virus vectors," Clinical Microbiology Reviews, vol. 21, no. 4, pp. 583-593, 2008.
[210] Y. Lai, Y. Yue, and D. Duan, "Evidence for the failure of adeno-associated virus serotype 5 to package a viral genome $\geq$ /=8.2kb," Molecular Therapy, vol. 18, no. 1, pp. 75-79, 2010.

[211] A. K. Zaiss and D. A. Muruve, "Immunity to adenoassociated virus vectors in animals and humans: a continued challenge," Gene Therapy, vol. 15, no. 11, pp. 808-816, 2008.

[212] K. Narfstrom, M. L. Katz, M. Ford, et al., "In vivo gene therapy in young and adult RPE65-/- dogs produces longterm visual improvement," Journal of Heredity, vol. 94, pp. 31-37, 2003.

[213] X. Sun, B. Pawlyk, X. Xu et al., "Gene therapy with a promoter targeting both rods and cones rescues retinal degeneration caused by AIPL1 mutations," Gene Therapy, vol. 17, no. 1, pp. 117-131, 2010.

[214] R. C. Rubenstein, U. McVeigh, T. R. Flotte, W. B. Guggino, and P. L. Zeitlin, "CFTR gene transduction in neonatal rabbits using an adeno-associated virus (AAV) vector," Gene Therapy, vol. 4, pp. 384-392, 1997.

[215] C. K. Conrad, S. S. Allen, S. A. Afione, et al., "Safety of singledose administration of an adeno-associated virus (AAV)CFTR vector in the primate lung," Gene Therapy, vol. 3, pp. 658-668, 1996.

[216] G. P. Niemeyer, R. W. Herzog, J. Mount, et al., "Long-term correction of inhibitor-prone hemophilia B dogs treated with liver-directed AAV2-mediated factor IX gene therapy," Blood, vol. 113, no. 4, pp. 797-806, 2009.

[217] C. Vitiello, S. Faraso, N. C. Sorrentino et al., "Disease rescue and increased lifespan in a model of cardiomyopathy and muscular dystrophy by combined AAV treatments," PLoS ONE, vol. 4, no. 3, Article ID e5051, 2009.

[218] D. Kuck, T. Lau, B. Leuchs et al., "Intranasal vaccination with recombinant adeno-associated virus type 5 against human papillomavirus type 16 L1," Journal of Virology, vol. 80, no. 6, pp. 2621-2630, 2006.

[219] C. Mueller and T. R. Flotte, "Clinical gene therapy using recombinant adeno-associated virus vectors," Gene Therapy, vol. 15, no. 11, pp. 858-863, 2008.

[220] M. J. McConnell and M. J. Imperiale, "Biology of adenovirus and its use as a vector for gene therapy," Human Gene Therapy, vol. 15, no. 11, pp. 1022-1033, 2004.

[221] G. Schiedner, N. Morral, R. J. Parks et al., "Genomic DNA transfer with a high-capacity adenovirus vector results in improved in vivo gene expression and decreased toxicity," Nature Genetics, vol. 18, no. 2, pp. 180-183, 1998.

[222] M. Christ, M. Lusky, F. Stoeckel et al., "Gene therapy with recombinant adenovirus vectors: evaluation of the host immune response," Immunology Letters, vol. 57, no. 1-3, pp. 19-25, 1997.

[223] C. Volpers and S. Kochanek, "Adenoviral vectors for gene transfer and therapy," Journal of Gene Medicine, vol. 6, no. 1, pp. S164-S171, 2004.

[224] A. Keriel, C. René, C. Galer, J. Zabner, and E. J. Kremer, "Canine adenovirus vectors for lung-directed gene transfer: efficacy, immune response, and duration of transgene expression using helper-dependent vectors," Journal of Virology, vol. 80, no. 3, pp. 1487-1496, 2006.

[225] F. Kreppel and S. Kochanek, "Modification of adenovirus gene transfer vectors with synthetic polymers: a scientific review and technical guide," Molecular Therapy, vol. 16, no. 1, pp. 16-29, 2008. 
[226] N. Brunetti-Pierri, T. Ng, D. A. Iannitti et al., "Improved hepatic transduction, reduced systemic vector dissemination, and long-term transgene expression by delivering helperdependent adenoviral vectors into the surgically isolated liver of nonhuman primates," Human Gene Therapy, vol. 17, no. 4, pp. 391-404, 2006.

[227] I. H. Kim, A. Jozkowicz, P. A. Piedra, K. Oka, and L. Chan, "Lifetime correction of genetic deficiency in mice with a single injection of helper-dependent adenoviral vector," Proceedings of the National Academy of Sciences of the United States of America, vol. 98, pp. 13282-13287, 2001.

[228] G. Toietta, V. P. Mane, W. S. Norona et al., "Lifelong elimination of hyperbilirubinemia in the Gunn rat with a single injection of helper-dependent adenoviral vector," Proceedings of the National Academy of Sciences of the United States of America, vol. 102, no. 11, pp. 3930-3935, 2005.

[229] L. Pastore, L. M. Belalcazar, K Oka, et al., "Helper-dependent adenoviral vector-mediated long-term expression of human apolipoprotein A-I reduces atherosclerosis in apo E-deficient mice," Gene, vol. 327, pp. 153-160, 2004.

[230] S. Van Linthout, M. Lusky, D. Collen, and B. De Geest, "Persistent hepatic expression of human apo A-1 after transfer with a helper-virus independent adenoviral vector," Gene Therapy, vol. 9, no. 22, pp. 1520-1528, 2002.

[231] D. P. Reay, R. Bilbao, B. M. Koppanati, et al., "Full-length dystrophin gene transfer to the mdx mouse in utero," Gene Therapy, vol. 15, pp. 531-536, 2008.

[232] P. R. Clemens, S. Kochanek, Y. Sunada et al., "In vivo muscle gene transfer of full-length dystrophin with an adenoviral vector that lacks all viral genes," Gene Therapy, vol. 3, no. 11, pp. 965-972, 1996.

[233] A. Kiang, Z. C. Hartman, S. Liao et al., "Fully deleted adenovirus persistently expressing GAA accomplishes longterm skeletal muscle glycogen correction in tolerant and nontolerant GSD-II mice," Molecular Therapy, vol. 13, no. 1, pp. 127-134, 2006.

[234] P. S. Reddy, K. Sakhuja, S. Ganesh et al., "Sustained human factor VIII expression in hemophilia A mice following systemic delivery of a gutless adenoviral vector," Molecular Therapy, vol. 5, no. 1, pp. 63-73, 2002.

[235] V. G. Sivanandam, S. L. Stephen, R. Hernandez-Alcoceba et al., "Lethality in an anti-angiogenic tumor gene therapy model upon constitutive but not inducible expression of the soluble vascular endothelial growth factor receptor 1," Journal of Gene Medicine, vol. 10, no. 10, pp. 1083-1091, 2008.

[236] Y. Kishi, K. Kuba, T. Nakamura et al., "Systemic NK4 gene therapy inhibits tumor growth and metastasis of melanoma and lung carcinoma in syngeneic mouse tumor models," Cancer Science, vol. 100, no. 7, pp. 1351-1358, 2009.

[237] J. J. Cody and J. T. Douglas, "Armed replicating adenoviruses for cancer virotherapy," Cancer Gene Therapy, vol. 16, no. 6, pp. 473-488, 2009.

[238] S. Lamartina, M. Cimino, G. Roscilli et al., "Helperdependent adenovirus for the gene therapy of proliferative retinopathies: stable gene transfer, regulated gene expression and therapeutic efficacy," Journal of Gene Medicine, vol. 9, no. 10, pp. 862-874, 2007.

[239] E. O. Ronan, L. N. Lee, P. C. Beverley, and E. Z. Tchilian, "Immunization of mice with a recombinant adenovirus vaccine inhibits the early growth of Mycobacterium tuberculosis after infection," PloS one, vol. 4, no. 12, Article ID e8235, 2009.
[240] T. Shirakawa, "Clinical trial design for adenoviral gene therapy products," Drug News and Perspectives, vol. 22, no. 3, pp. 140-145, 2009.

[241] Y.-S. Guan, Y. Liu, Q. Zou et al., "Adenovirus-mediated wildtype p53 gene transfer in combination with bronchial arterial infusion for treatment of advanced non-small-cell lung cancer, one year follow-up," Journal of Zhejiang University, vol. 10, no. 5, pp. 331-340, 2009.

[242] G. L. Buchschacher Jr., "Introduction to retroviruses and retroviral vectors," Somatic Cell and Molecular Genetics, vol. 26, pp. 1-11, 2001.

[243] D. Escors and K. Breckpot, "Lentiviral vectors in gene therapy: their current status and future potential," Archivum Immunologiae et Therapiae Experimentalis, vol. 58, no. 2, pp. 107-119, 2010.

[244] A. Blesch, "Lentiviral and MLV based retroviral vectors for ex vivo and in vivo gene transfer," Methods, vol. 33, pp. 164-172, 2004.

[245] R. Zufferey, T. Dull, R. J. Mandel et al., "Self-inactivating lentivirus vector for safe and efficient in vivo gene delivery," Journal of Virology, vol. 72, no. 12, pp. 9873-9880, 1998.

[246] J. Kulkosky and A. M. Skalka, "Molecular mechanism of retroviral DNA integration," Pharmacology and Therapeutics, vol. 61, no. 1-2, pp. 185-203, 1994.

[247] S. P. Quenneville, P. Chapdelaine, D. Skuk et al., "Autologous transplantation of muscle precursor cells modified with a lentivirus for muscular dystrophy: human cells and primate models," Molecular Therapy, vol. 15, no. 2, pp. 431-438, 2007.

[248] J. S. Powell, M. V. Ragni, G. C. White II et al., "Phase 1 trial of FVIII gene transfer for severe hemophilia A using a retroviral construct administered by peripheral intravenous infusion," Blood, vol. 102, no. 6, pp. 2038-2045, 2003.

[249] A. González-Murillo, M. L. Lozano, L. Álvarez et al., "Development of lentiviral vectors with optimized transcriptional activity for the gene therapy of patients with fanconi anemia," Human Gene Therapy, vol. 21, no. 5, pp. 623-630, 2010.

[250] C. Lundberg, T. Björklund, T. Carlsson et al., "Applications of lentiviral vectors for biology and gene therapy of neurological disorders," Current Gene Therapy, vol. 8, no. 6, pp. 461-473, 2008.

[251] K. Breckpot, P. U. Emeagi, and K. Thielemans, "Lentiviral vectors for anti-tumor immunotherapy," Current Gene Therapy, vol. 8, no. 6, pp. 438-448, 2008.

[252] A. Aiuti and M. G. Roncarolo, "Ten years of gene therapy for primary immune deficiencies," Hematology/American Society of Hematology. Education Program, pp. 682-689, 2009.

[253] A. Miyanohara, M. F. Sharkey, J. L. Witztum, D. Steinberg, and T. Friedmann, "Efficient expression of retroviral vectortransduced human low density lipoprotein (LDL) receptor in LDL receptor-deficient rabbit fibroblasts in vitro," Proceedings of the National Academy of Sciences of the United States of America, vol. 85, no. 17, pp. 6538-6542, 1988.

[254] J. M. Wilson, L. K. Birinyi, R. N. Salomon, P. Libby, A. D. Callow, and R. C. Mulligan, "Implantation of vascular grafts lined with genetically modified endothelial cells," Science, vol. 244, no. 4910, pp. 1344-1346, 1989.

[255] E. G. Nabel, G. Plautz, F. M. Boyce, J. C. Stanley, and G. J. Nabel, "Recombinant gene expression in vivo within endothelial cells of the arterial wall," Science, vol. 244, pp. 1342-1344, 1989.

[256] A. Nicoletti, G. Caligiuri, I. Törnberg, T. Kodama, S. Stemme, and G. K. Hansson, "The macrophage scavenger receptor 
type A directs modified proteins to antigen presentation," European The Journal of Immunology, vol. 29, no. 2, pp. 512$521,1999$.

[257] N. Platt, H. Suzuki, Y. Kurihara, T. Kodama, and S. Gordon, "Role for the class A macrophage scavenger receptor in the phagocytosis of apoptotic thymocytes in vitro," Proceedings of the National Academy of Sciences of the United States of America, vol. 93, no. 22, pp. 12456-12460, 1996.

[258] J. Santiago-García, J. Mas-Olivata, T. L. Innerarity, and R. E. Pitas, "Secreted Forms of the Amyloid- $\beta$ Precursor Protein are Ligands for the Class A Scavenger Receptor," The Journal of Biological Chemistry, vol. 276, no. 33, pp. 30655-30661, 2001.

[259] H. K. Usui, K. Shikata, M. Sasaki et al., "Macrophage scavenger receptor-A-deficient mice are resistant against diabetic nephropathy through amelioration of microinflammation," Diabetes, vol. 56, no. 2, pp. 363-372, 2007.

[260] D. P.Y. Koonen, M. Febbraio, S. Bonnet et al., "CD36 expression contributes to age-induced cardiomyopathy in mice," Circulation, vol. 116, no. 19, pp. 2139-2147, 2007.

[261] K. J. Moore and M. W. Freeman, "Scavenger receptors in atherosclerosis: beyond lipid uptake," Arteriosclerosis, Thrombosis, and Vascular Biology, vol. 26, no. 8, pp. 17021711, 2006.

[262] S. J. White, S. A. Nicklin, T. Sawamura, and A. H. Baker, "Identification of peptides that target the endothelial cellspecific LOX-1 receptor," Hypertension, vol. 37, pp. 449-455, 2001.

[263] Y. Ishigaki, H. Katagiri, J. Gao et al., "Impact of plasma oxidized low-density lipoprotein removal on atherosclerosis," Circulation, vol. 118, no. 1, pp. 75-83, 2008.

[264] P. Lehtolainen, M. Takeya, and S. Ylä-Herttuala, "Retrovirusmediated, stable scavenger-receptor gene transfer leads to functional endocytotic receptor expression, foam cell formation, and increased susceptibility to apoptosis in rabbit aortic smooth muscle cells," Arteriosclerosis, Thrombosis, and Vascular Biology, vol. 20, no. 1, pp. 52-60, 2000.

[265] J. Laukkanen, P. Lehtolainen, P. J. Gough, D. R. Greaves, S. Gordon, and Y.-H. Seppo, "Adenovirus-mediated gene transfer of a secreted form of human macrophage scavenger receptor inhibits modified low-density lipoprotein degradation and foam-cell formation in macrophages," Circulation, vol. 101, no. 10, pp. 1091-1096, 2000.

[266] J. Jalkanen, P. Leppänen, O. Närvänen, D. R. Greaves, and S. Ylä-Herttuala, "Adenovirus-mediated gene transfer of a secreted decoy human macrophage scavenger receptor (SRAI) in LDL receptor knock-out mice," Atherosclerosis, vol. 169, no. 1, pp. 95-103, 2003.

[267] J. Jalkanen, P. Leppänen, K. Pajusola et al., "Adenoassociated virus-mediated gene transfer of a secreted decoy human macrophage scavenger receptor reduces atherosclerotic lesion formation in LDL receptor knockout mice," Molecular Therapy, vol. 8, no. 6, pp. 903-910, 2003.

[268] I. Tancevski, S. Frank, P. Massoner et al., "Increased plasma levels of LDL cholesterol in rabbits after adenoviral overexpression of human scavenger receptor class B type I," Journal of Molecular Medicine, vol. 83, no. 11, pp. 927-932, 2005.

[269] H. Wiersma, A. Gatti, N. Nijstad, R. P.J. Oude Elferink, F. Kuipers, and U. J.F. Tietge, "Scavenger receptor class B type I mediates biliary cholesterol secretion independent of ATPbinding cassette transporter g5/g8 in mice," Hepatology, vol. 50, no. 4, pp. 1263-1272, 2009.
[270] S. Zhong, C. Liu, D. Haviland, P. A. Doris, and B.-B. Teng, "Simultaneous expression of apolipoprotein B mRNA editing enzyme and scavenger receptor BI mediated by a therapeutic gene expression system," Atherosclerosis, vol. 184, no. 2, pp. 264-275, 2006.

[271] W. J.S. de Villiers, L. Cai, N. R. Webb, M. C. de Beer, D. R. van der Westhuyzen, and F. C. de Beer, "CD36 does not play a direct role in HDL or LDL metabolism," Journal of Lipid Research, vol. 42, no. 8, pp. 1231-1238, 2001.

[272] B. Sun, B. B. Boyanovsky, M. A. Connelly, P. Shridas, D. R. van der Westhuyzen, and N. R. Webb, "Distinct mechanisms for OxLDL uptake and cellular trafficking by class B scavenger receptors CD36 and SR-BI," Journal of Lipid Research, vol. 48, no. 12, pp. 2560-2570, 2007.

[273] D. P. Koonen, R. L. Jacobs, M. Febbraio, et al., "Increased hepatic CD36 expression contributes to dyslipidemia associated with diet-induced obesity," Diabetes, vol. 56, pp. 28632871, 2007.

[274] K. Kvell, T. Czömpöly, T. Pikkarainen, and P. Balogh, "Species-specific restriction of cell surface expression of mouse MARCO glycoprotein in murine cell lines," Biochemical and Biophysical Research Communications, vol. 341, no. 4, pp. 1193-1202, 2006.

[275] H. J. Haisma, M. Boesjes, A. M. Beerens et al., "Scavenger receptor A: a new route for adenovirus 5," Molecular Pharmaceutics, vol. 6, no. 2, pp. 366-374, 2009.

[276] S. Acton, A. Rigotti, K. T. Landschulz, S. Xu, H. H. Hobbs, and M. Kriegert, "Identification of scavenger receptor SR-BI as a high density lipoprotein receptor," Science, vol. 271, no. 5248, pp. 518-520, 1996.

[277] A. M. Scanu and C. Edelstein, "HDL: bridging past and present with a look at the future," The FASEB Journal, vol. 22, no. 12, pp. 4044-4054, 2008.

[278] N. Wang, T. Arai, Y. Ji, F. Rinninger, and A. R. Tall, "Liverspecific overexpression of scavenger receptor BI decreases levels of very low density lipoprotein ApoB, low density lipoprotein ApoB, and high density lipoprotein in transgenic mice," The Journal of Biological Chemistry, vol. 273, no. 49, pp. 32920-32926, 1998.

[279] N. R. Webb, M. C. de Beer, J. Yu et al., "Overexpression of SR-BI by adenoviral vector promotes clearance of apoA-I, but not apoB, in human apoB transgenic mice," Journal of Lipid Research, vol. 43, no. 9, pp. 1421-1428, 2002.

[280] N. R. Webb, L. Cai, K. S. Ziemba et al., "The fate of HDL particles in vivo after SR-BI-mediated selective lipid uptake," Journal of Lipid Research, vol. 43, no. 11, pp. 1890-1898, 2002.

[281] I. S. Yuhanna, Y. Zhu, B. E. Cox et al., "High-density lipoprotein binding to scavenger receptor-BI activates endothelial nitric oxide synthase," Nature Medicine, vol. 7, no. 7, pp. 853857, 2001.

[282] C. C. Schwartz, J. M. VandenBroek, and P. S. Cooper, "Lipoprotein cholesteryl ester production, transfer, and output in vivo in humans," Journal of Lipid Research, vol. 45, no. 9, pp. 1594-1607, 2004.

[283] D. Osgood, D. Corella, S. Demissie et al., "Genetic variation at the scavenger receptor class B type I gene locus determines plasma lipoprotein concentrations and particle size and interacts with type 2 diabetes: the Framingham study," Journal of Clinical Endocrinology and Metabolism, vol. 88, no. 6, pp. 2869-2879, 2003.

[284] G. Endemann, L. W. Stanton, K. S. Madden, C. M. Bryant, R. T. White, and A. A. Protter, "CD36 is a receptor for oxidized low density lipoprotein," The Journal of Biological Chemistry, vol. 268, no. 16, pp. 11811-11816, 1993. 
[285] D. M. Wuttge, X. Zhou, Y. Sheikine et al., "CXCL16/SRPSOX is an interferon- $\gamma$-regulated chemokine and scavenger receptor expressed in atherosclerotic lesions," Arteriosclerosis, Thrombosis, and Vascular Biology, vol. 24, no. 4, pp. 750-755, 2004.

[286] M. Tohyama, K. Sayama, H. Komatsuzawa et al., "CXCL16 is a novel mediator of the innate immunity of epidermal keratinocytes," International Immunology, vol. 19, no. 9, pp. 1095-1102, 2007.

[287] A. Ramezani, T. S. Hawley, and R. G. Hawley, "Combinatorial incorporation of enhancer-blocking components of the chicken $\beta$-globin 5'HS4 and human T-cell receptor $\alpha / \delta$ BEAD-1 insulators in self-inactivating retroviral vectors reduces their genotoxic potential," Stem Cells, vol. 26, no. 12, pp. 3257-3266, 2008.

[288] G. D. Trobridge, D. G. Miller, M. A. Jacobs et al., "Foamy virus vector integration sites in normal human cells," Proceedings of the National Academy of Sciences of the United States of America, vol. 103, no. 5, pp. 1498-1503, 2006.

[289] T. C. Mast, L. Kierstead, S. B. Gupta et al., "International epidemiology of human pre-existing adenovirus (Ad) type5 , type-6, type-26 and type-36 neutralizing antibodies: correlates of high Ad5 titers and implications for potential HIV vaccine trials," Vaccine, vol. 28, no. 4, pp. 950-957, 2010.

[290] J. Crettaz, P. Berraondo, I. Mauleón et al., "Intrahepatic injection of adenovirus reduces inflammation and increases gene transfer and therapeutic effect in mice," Hepatology, vol. 44, no. 3, pp. 623-632, 2006.

[291] L. Yang, L. Bailey, D. Baltimore, and P. Wang, "Targeting lentiviral vectors to specific cell types in vivo," Proceedings of the National Academy of Sciences of the United States of America, vol. 103, pp. 11479-11484, 2006.

[292] W. H. Miller, M. J. Brosnan, D. Graham, et al., “Targeting endothelial cells with adenovirus expressing nitric oxide synthase prevents elevation of blood pressure in stroke-prone spontaneously hypertensive rats," Molecular Therapy, vol. 12, pp. 321-327, 2005.

[293] D. M. Nettelbeck, D. W. Miller, V. Jérôme et al., "Targeting of adenovirus to endothelial cells by a bispecific single-chain diabody directed against the adenovirus fiber knob domain and human endoglin (CD105)," Molecular Therapy, vol. 3, no. 6, pp. 882-891, 2001.

[294] Z. Qian, M. Haessler, J. A. Lemos et al., "Targeting vascular injury using hantavirus-pseudotyped lentiviral vectors," Molecular Therapy, vol. 13, no. 4, pp. 694-704, 2006.

[295] D. Escors, L. Lopes, R. Lin, et al., "Targeting dendritic cell signaling to regulate the response to immunization," Blood, vol. 111, pp. 3050-3061, 2008. 


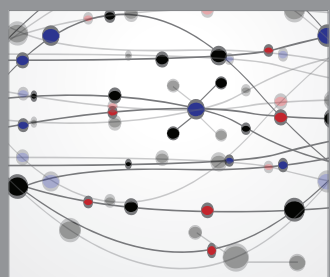

The Scientific World Journal
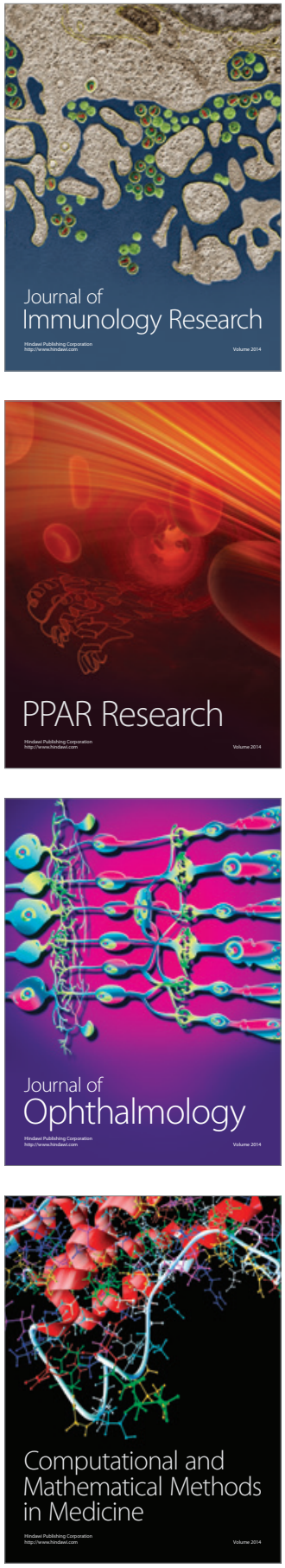

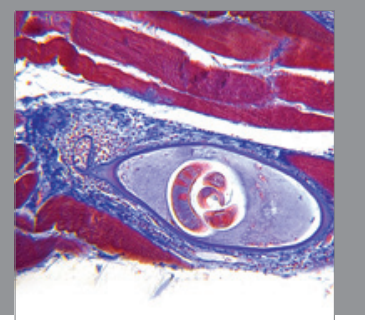

Gastroenterology

Research and Practice
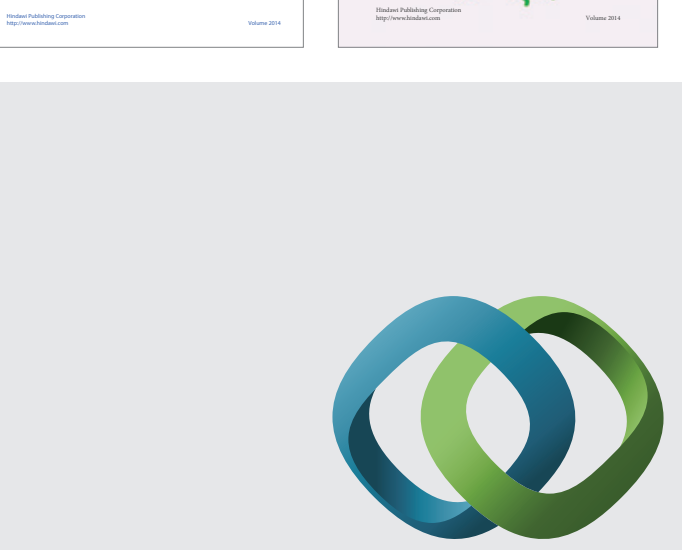

\section{Hindawi}

Submit your manuscripts at

http://www.hindawi.com
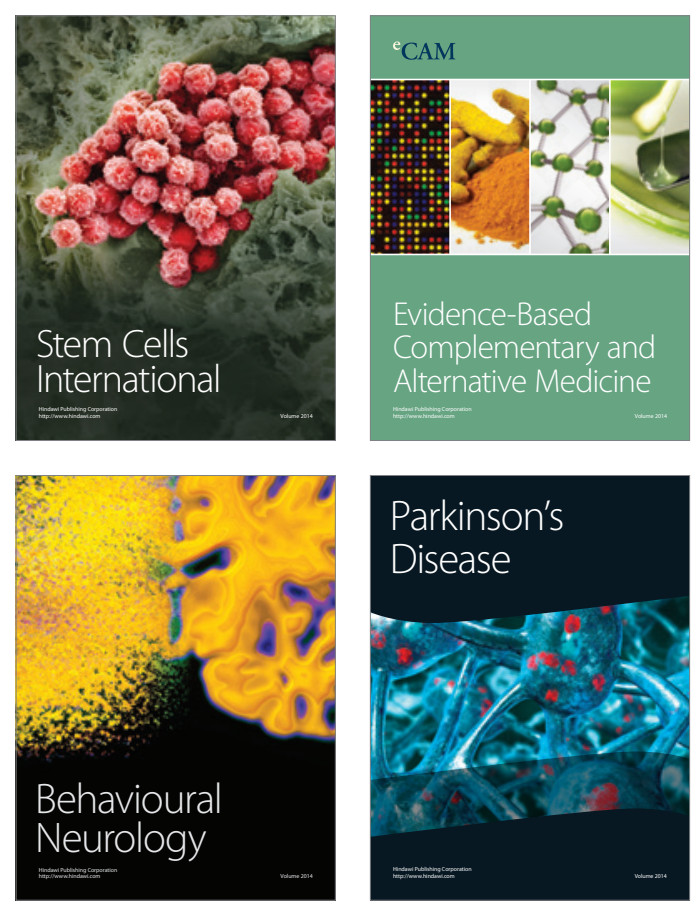

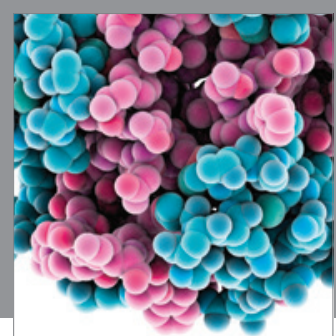

Journal of
Diabetes Research

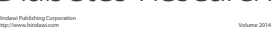

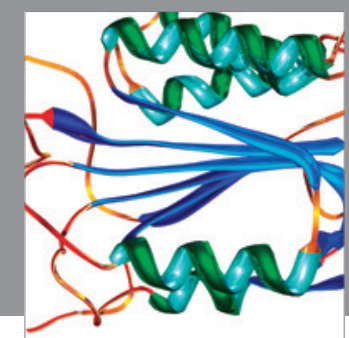

Disease Markers
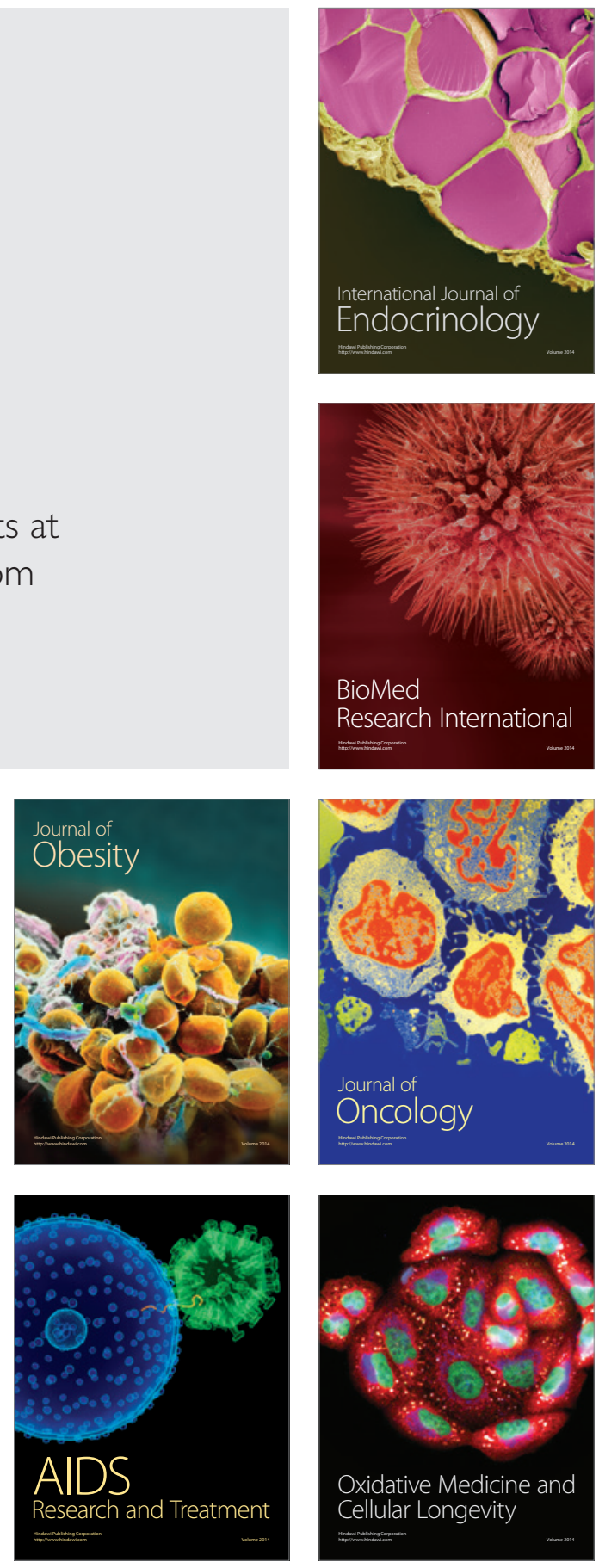